
August 2000
- NREL/TP-620-28674

\title{
REPiS: The Renewable Electric Plant Information System
}

\section{Edition}

K. Porter, D. Trickett, and L. Bird

\section{National Renewable Energy Laboratory}

1617 Cole Boulevard

Golden, Colorado 80401-3393

NREL is a U.S. Department of Energy Laboratory

Operated by Midwest Research Institute • Battelle • Bechtel

Contract No. DE-AC36-99-G010337 


\title{
REPiS: The Renewable Electric Plant Information System
}

\section{Edition}

\author{
K. Porter, D. Trickett, and L. Bird
}

Prepared under Task No. AS65.4010

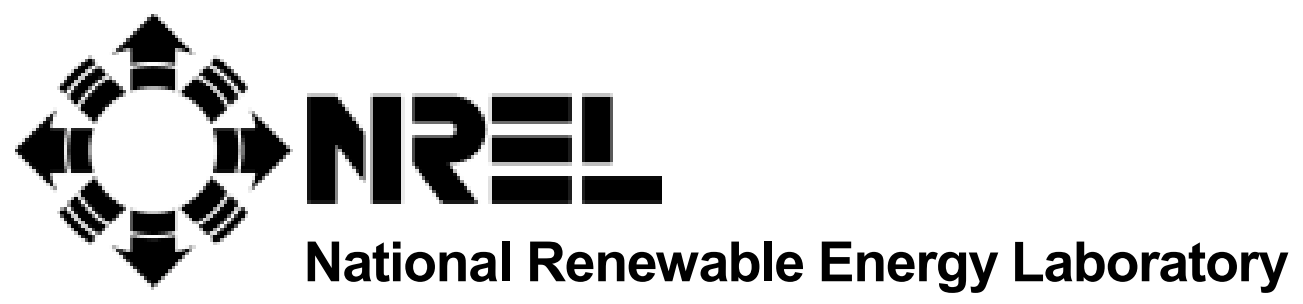

1617 Cole Boulevard

Golden, Colorado 80401-3393

NREL is a U.S. Department of Energy Laboratory

Operated by Midwest Research Institute • Battelle • Bechtel

Contract No. DE-AC36-99-G010337 


\section{NOTICE}

This report was prepared as an account of work sponsored by an agency of the United States government. Neither the United States government nor any agency thereof, nor any of their employees, makes any warranty, express or implied, or assumes any legal liability or responsibility for the accuracy, completeness, or usefulness of any information, apparatus, product, or process disclosed, or represents that its use would not infringe privately owned rights. Reference herein to any specific commercial product, process, or service by trade name, trademark, manufacturer, or otherwise does not necessarily constitute or imply its endorsement, recommendation, or favoring by the United States government or any agency thereof. The views and opinions of authors expressed herein do not necessarily state or reflect those of the United States government or any agency thereof.

Available electronically at http://www.doe.gov/bridge

Available for a processing fee to U.S. Department of Energy

and its contractors, in paper, from:

U.S. Department of Energy

Office of Scientific and Technical Information

P.O. Box 62

Oak Ridge, TN 37831-0062

phone: 865.576.8401

fax: 865.576.5728

email: reports@adonis.osti.gov

Available for sale to the public, in paper, from:

U.S. Department of Commerce

National Technical Information Service

5285 Port Royal Road

Springfield, VA 22161

phone: 800.553.6847

fax: 703.605.6900

email: orders@ntis.fedworld.gov

online ordering: http://www.ntis.gov/ordering.htm

Printed on paper containing at least $50 \%$ wastepaper, including $20 \%$ postconsumer waste 


\section{Contents}

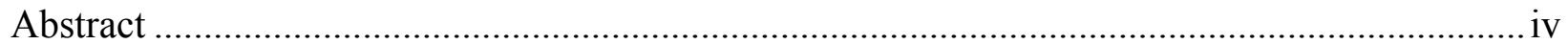

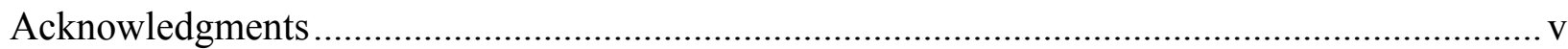

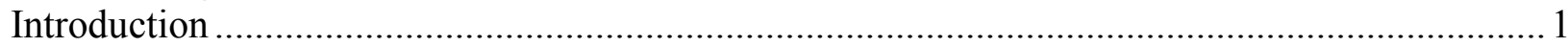

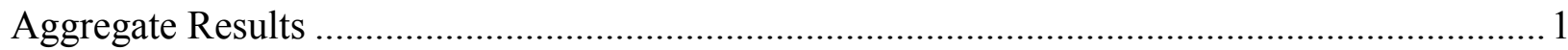

Operating Renewable Electric Plants by Technology ......................................................... 4

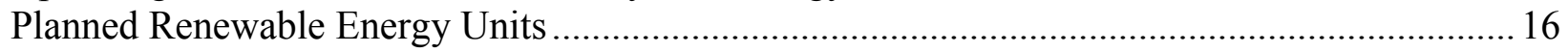

Leading States in Renewable Energy Capacity Development ............................................... 17

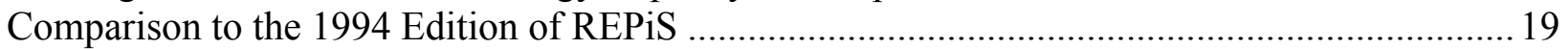

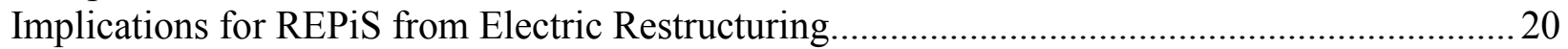

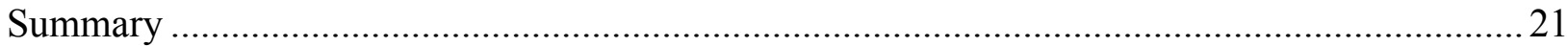

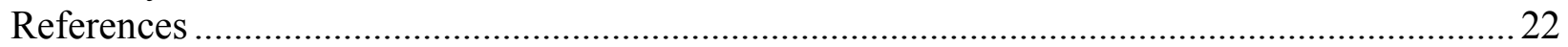

\section{Appendices}

Appendix A: Operating and Planned Renewable Electric Capacity by State .........................A-1

Appendix B: Primary Data Fields .....................................................................................

Appendix C: Plant Name, Location, and Utility Table ...................................................... -1

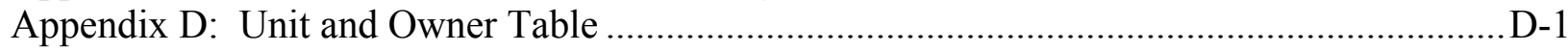

Appendix E: Database Design and Methodology …........................................................ E-1

\section{Tables}

Table 1. Definitions of Plant Operating Status in REPiS....................................................... 2

Table 2. Summary of Units and Capacity in REPiS by Current Status ..................................... 2

Table 3. Capacity and Operating Status by Technology $(\mathrm{kW})$............................................. 3

Table 4. Operating Units and Capacity $(\mathrm{kW})$ in REPiS of Biomass, by Fuel Source................... 4

Table 5. Summary of Agricultural Waste Capacity in REPiS, by Current Status ....................... 4

Table 6. Summary of Biogas Capacity in REPiS, by Current Status ........................................ 5

Table 7. Summary of Waste-to-Energy Capacity in REPiS, by Current Status........................... 7

Table 8. Summary of Wood Residue Capacity in REPiS, by Current Status ............................. 8

Table 9. Summary of Geothermal Capacity in REPiS, by Current Status .................................. 9

Table 10. Summary of Hydro Capacity in REPiS, by Current Status...................................... 11

Table 11. Summary of Photovoltaics Capacity in REPiS, by Current Status ............................ 12

Table 12. Summary of Solar Thermal Electric Capacity in REPiS, by Current Status .............. 14

Table 13. Summary of Wind Energy Capacity in REPiS, by Current Status ............................ 15

Table 14. Planned Renewable Units and Capacity by Technology by REPiS Edition................ 17

Table 15. States with the Most Operating Renewable Energy Capacity in REPiS.................... 18

Table 16. States with the Most Operating Non-Hydro Renewable Energy Capacity in REPiS .. 18

Table 17. States with the Most Planned Renewable Energy Capacity...................................... 19

Table 18. Comparison in Capacity (kW) Between REPiS III and REPiS IV, by Technology .... 19 
Table 19. Comparison in Capacity (kW) Between EIA and REPiS, by Technology .................20

Table A-1. Operating Renewable Electric Capacity by State $(\mathrm{kW})$.........................................2

Table A-2. Planned Capacity by Technology and State $(\mathrm{kW})$..............................................

Table A-3. Summary of Cancelled Capacity in REPiS, by Renewable Fuel Source.................A-5

Table A-4. States with the Most Operating Agricultural Waste Capacity in REPiS .................A-5

Table A-5. States with the Most Operating Geothermal Capacity in REPiS ............................ A-5

Table A-6. States with the Most Operating Hydro Capacity in REPiS ..................................6

Table A-7. States with the Most Operating Biogas Capacity in REPiS.................................A-6

Table A-8. States with the Most Operating Municipal Solid Waste Capacity in REPiS ...........A-6

Table A-9. States with the Most Operating Photovoltaics Capacity in REPiS ..........................

Table A-10. States with the Most Operating Wind Capacity in REPiS .................................A-7

Table A-11. States with the Most Operating Wood Residue Capacity in REPiS .....................A-7

Table B-1. Primary Data Fields....................................................................................... B-2

Table C-1. Plant Name, Location, and Utility Table Structure .............................................

Table C-2 Relationship between Plant and Utility............................................................. C-1

Table C-3. State Code and FERC Region ..............................................................................

Table D-1. Unit and Owner Table Structure ................................................................. D-1

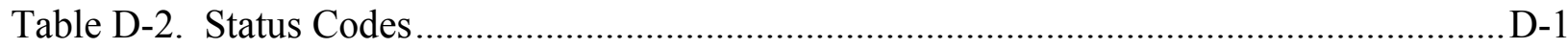

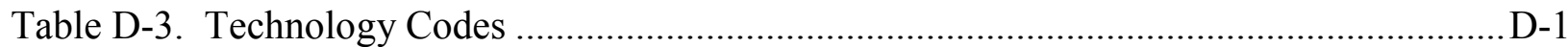

Table D-4. System Type Codes.........................................................................................

Table D-5. Fuel Codes ........................................................................................................... D-3

Table D-6. Bioenergy (Biomass) Fuel Code Descriptions................................................... D-3

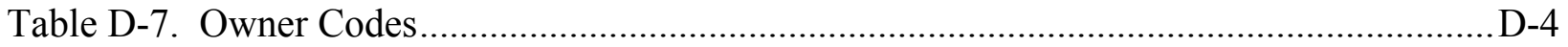

\section{Figures}

Figure 1. Cumulative Operating Renewable Energy Capacity by Year ................................... 3

Figure 2. Cumulative Operating Agricultural Waste Capacity by Year ..................................... 5

Figure 3. Cumulative Operating Biogas Capacity by Year....................................................... 6

Figure 4. Cumulative Operating Waste-to-Energy Capacity by Year ...................................... 7

Figure 5. Cumulative Operating Wood Residue Capacity by Year ...........................................9

Figure 6. Cumulative Operating Geothermal Capacity by Year .......................................... 10

Figure 7. Cumulative Operating Hydro Capacity by Year................................................... 12

Figure 8. Cumulative Operating Photovoltaics Capacity by Year ........................................... 13

Figure 9. Cumulative Operating and Planned Solar Thermal Capacity by Year ....................... 14

Figure 10. Cumulative Operating and Planned Wind Energy Capacity by Year....................... 15

Figure 11. Planned Renewable Electric Capacity by Year Expected On-Line (MW)................ 16 


\begin{abstract}
This technical report summarizes the data in the Renewable Electric Plant Information System (REPiS), a database of all known grid-connected renewable electric facilities in the United States. It was originally designed in 1985 and updated in 1990 and 1994 (Swezey and Porter 1988; Swezey and Porter 1990; Sinclair 1994). We discuss how the database is designed, and summarize some of the results of common search queries of the database. Data is presented on the amount of renewable electric capacity nationally that is operated, retired, planned or of unknown status, as well as operating and planned renewable electric capacity by state. We then compare the REPiS data to the 1994 edition of REPiS, and also to data published by the U.S. Energy Information Administration. We also note that electric restructuring will change how electric power data is collected and maintained; this may prompt some changes in future editions of REPiS. The REPiS database is available on the Internet at http://www.eren.doe.gov/repis.
\end{abstract}




\section{Acknowledgments}

The authors wish to thank Joe Galdo of the U.S. Department of Energy's Office of Power Technologies, in the Office of Energy Efficiency and Renewable Energy, for funding this project. Jim Leyshon, Brandon Owens, and France Mahan of the National Renewable Energy Laboratory (NREL) helped load the database onto the Renewable Electric Plant Information System (REPiS) Web Site. Dr. Adam Serchuk of the Renewable Energy Policy Project, Ryan Wiser of Lawrence

Berkeley National Laboratory, and Larry Goldstein, Eldon Boes, Blair Swezey, and Karin Sinclair of the National Renewable Energy Laboratory (NREL) provided helpful comments on the draft report. Stuart Smoller of NREL edited this report. Ray Fortuna, Thomas Rueckert, John Flynn, and Lynne Gillette of the U.S. Department of Energy - as well as Christy Herig, Henry Price, Brian Parsons, Kevin Craig, Phil Shepherd, and Chuck Kutscher of NREL, Carl Vansant of HCI Publications and Kevin Comer of Antares Corp.-reviewed individual technology sections of the draft report. We also thank the numerous state energy offices, state public utility commissions, and representatives from renewable energy companies and electric utilities around the nation that provided helpful information and feedback throughout this project. 


\section{REPiS: \\ The Renewable Electric Plant Information System 1999 Edition}

\section{Introduction}

The Renewable Electric Plant Information System (REPiS) is a database of grid-connected renewable electric facilities, and is aimed at cataloging all known renewable electric facilities in the United States and making the data publicly available on an Internet site. The National Renewable Energy Laboratory (NREL) began the REPiS database in 1986. NREL has updated it periodically since then. The 1999 edition is the fourth update of REPiS. It represents a "best effort" at compiling an inventory of all known U.S. grid-connected renewable electric facilities through a large and systematic literature search. REPiS is a useful tool for researchers who want more detailed information on individual projects, renewable energy companies, or small renewable energy projects that are often overlooked in other databases. It will also benefit those who want to sort or manipulate data on renewable electric plants for their own individual research needs.

The REPiS database and common search queries are available on the Internet at http://www.eren.doe.gov/repis. Although every effort was made to determine the status of each entry in the database, there were several facilities for which the operating status could not be determined, and which are listed as unknown. We encourage those who have information on these projects, or with any other corrections or additions to REPiS, to contact the authors, or to send an e-mail at the Internet site.

This technical report presents some of the results from the REPiS database, and offers a perspective on how electric restructuring may affect electric power data collection, and therefore how future editions of REPiS could be conducted. Section II summarizes, in aggregate, data on the operational status by renewable energy technology. Section III breaks out the REPiS data by technology and discusses market trends over time for each technology, and some of the contributing policy and market factors. Section IV provides data on planned renewable energy units. Section V highlights the 10 states with the most renewable energy capacity and non-hydro renewable energy capacity, respectively. Section VI compares the data in this edition of REPiS with the 1994 edition of REPiS and with data on renewable electric technologies maintained by the U.S. Energy Information Administration (EIA). Section VII discusses how changes in data collection and availability, in response to electric industry restructuring, may affect future editions of REPiS. The report ends with a summary.

\section{Aggregate Results}

REPiS includes information on the following renewable energy technologies: biomass (agricultural waste, biogas, waste-to-energy [WTE] and wood residues); geothermal; small and large hydro (including pumped storage); photovoltaics (PV); solar thermal electric; and wind. REPiS contains information on 8,066 renewable energy plants that are grid-connected, and encompasses plants that are operating, planned, retired, in standby or testing, or where the status is unknown because of lack of information. Table 1 shows how operating status is defined in REPiS. 
Table 1. Definitions of Plant Operating Status in REPiS

\begin{tabular}{|l|l|}
\hline \multicolumn{1}{|c|}{ Plant Status } & \multicolumn{1}{c|}{ Definition } \\
\hline Operating & Unit is in operation and generating electricity. \\
\hline Retired & $\begin{array}{l}\text { Unit was in operation but has been removed from service because of age } \\
\text { or economics. }\end{array}$ \\
\hline Unknown & $\begin{array}{l}\text { A unit may be operating or not operating, but the plant's operating status } \\
\text { cannot be determined. }\end{array}$ \\
\hline Planned & $\begin{array}{l}\text { A unit is projected to be in operation at some future date. A planned unit } \\
\text { is listed in REPiS if project plans have been announced through company } \\
\text { press releases, trade press, and so on. }\end{array}$ \\
\hline Cancelled & $\begin{array}{l}\text { A unit previously listed as planned but is no longer expected to be in } \\
\text { operation because of regulatory or economic considerations. }\end{array}$ \\
\hline Out of Service & $\begin{array}{l}\text { A unit normally in operation but has been removed from service for } \\
\text { maintenance or repair. }\end{array}$ \\
\hline Standby & $\begin{array}{l}\text { A unit that supports a utility system and is available to replace or } \\
\text { supplement a facility normally in service. }\end{array}$ \\
\hline Testing & $\begin{array}{l}\text { A new unit that is in testing and providing electric power to the grid but is } \\
\text { not yet in commercial operation. }\end{array}$ \\
\hline
\end{tabular}

Renewable electric plants in REPiS may be sub-divided into units to reflect capacity additions over time to a specific renewable electric plant. For example, the 1,037-megawatt (MW) Hoover hydro plant in Nevada is listed as one plant and 14 units in REPiS, to show that the first unit was added in 1936 and the most recent unit was added in 1961. The 8,066 renewable electric plants are represented in 8,193 units, for an overall total of about 117,225 MW of renewable energy capacity. Of this, 6,819 units (about 83\%) are currently operating, representing about 111,000 MW. Table 2 provides a breakdown by unit and plant status. REPiS also includes information on cancelled units, and these are identified separately in Table A-3 in Appendix A.

Table 2. Summary of Renewable Electric Plant, Units and Capacity (kilowatts [kW]) in REPiS, by Current Status

\begin{tabular}{|l|c|r|r|}
\hline Status & No. of Plants & No. of Units & Capacity (kW) \\
\hline Operating & 6,730 & 6,819 & $111,027,155$ \\
\hline Retired & 734 & 760 & $2,517,866$ \\
\hline Unknown & 311 & 313 & 990,710 \\
\hline Planned & 241 & 251 & $2,320,738$ \\
\hline Out of Service & 44 & 44 & 195,659 \\
\hline Standby & 4 & 4 & 16,325 \\
\hline Testing & 2 & 2 & 156,760 \\
\hline Total & 8,066 & 8,193 & $117,225,213$ \\
\hline
\end{tabular}


Table 3 shows the installed capacity and status of each technology in REPiS. Hydro accounts for over 96 gigawatts $(\mathrm{GW})$ of the $117 \mathrm{GW}$ in REPiS. Pumped storage hydro accounts for $19.6 \mathrm{GW}$ of the $96 \mathrm{GW}$ of hydro in REPiS.

Table 3. Capacity and Operating Status by Technology (kW)

\begin{tabular}{|l|r|r|r|r|r|r|r|r|}
\hline Fuel Source & Operating & Planned & Retired & $\begin{array}{c}\text { Out of } \\
\text { Service }\end{array}$ & Standby & Testing & $\begin{array}{c}\text { Unknown } \\
\text { Status }\end{array}$ & $\begin{array}{c}\text { Total } \\
\text { Capacity }\end{array}$ \\
\hline Ag Waste & 357,773 & 7,800 & 358,212 & & & & 90 & 723,875 \\
\hline Biogas & $1,063,949$ & 195,896 & 67,825 & 4,618 & 7,200 & & 4,425 & $1,343,913$ \\
\hline Waste-to-Energy & $2,563,038$ & & 476,898 & 1,200 & & & 72,550 & $3,113,686$ \\
\hline Wood Residues & $6,584,827$ & 68,800 & 477,211 & & 8,625 & & 64,700 & $7,204,164$ \\
\hline Total Biomass & $10,569,588$ & 272,496 & $1,380,146$ & 9,818 & 15,825 & 141,765 & $12,385,638$ \\
\hline Geothermal & $2,697,150$ & 225,499 & 398,120 & 55,000 & & & 272,000 & $3,647,769$ \\
\hline Hydro* & $94,789,367$ & 579,910 & 414,362 & 109,624 & 500 & 156,760 & 406,243 & $96,456,766$ \\
\hline Photovoltaics & 15,432 & 66,773 & 7,562 & 3 & & & 117 & 89,886 \\
\hline Solar Thermal & 353,925 & 2,000 & 15,575 & & & & 8 & 371,508 \\
\hline Wind & $2,601,694$ & $1,174,060$ & 302,100 & 25,214 & & & 170,578 & $4,273,647$ \\
\hline Total & $111,027,155$ & $2,320,738$ & $2,517,866$ & 195,659 & 16,325 & 156,760 & 990,710 & $117,225,213$ \\
\hline
\end{tabular}

* Includes pumped storage hydro.

Figure 1 represents cumulative operating renewable energy capacity by year, and includes hydro and non-hydro renewable energy technologies. Renewable energy capacity remained relatively low until large hydro facilities were constructed, beginning in the 1940s. Large hydro continued to increase overall renewable energy capacity until the 1970s, when non-hydro renewable energy capacity started coming on-line in response to the Public Utility Regulatory Policies Act of 1978 (PURPA). Growth in renewable energy capacity began to slow in the 1990s, in part because of market uncertainties and greater competition from various state electric restructuring initiatives.

Figure 1. Cumulative Operating Renewable Energy Capacity by Year

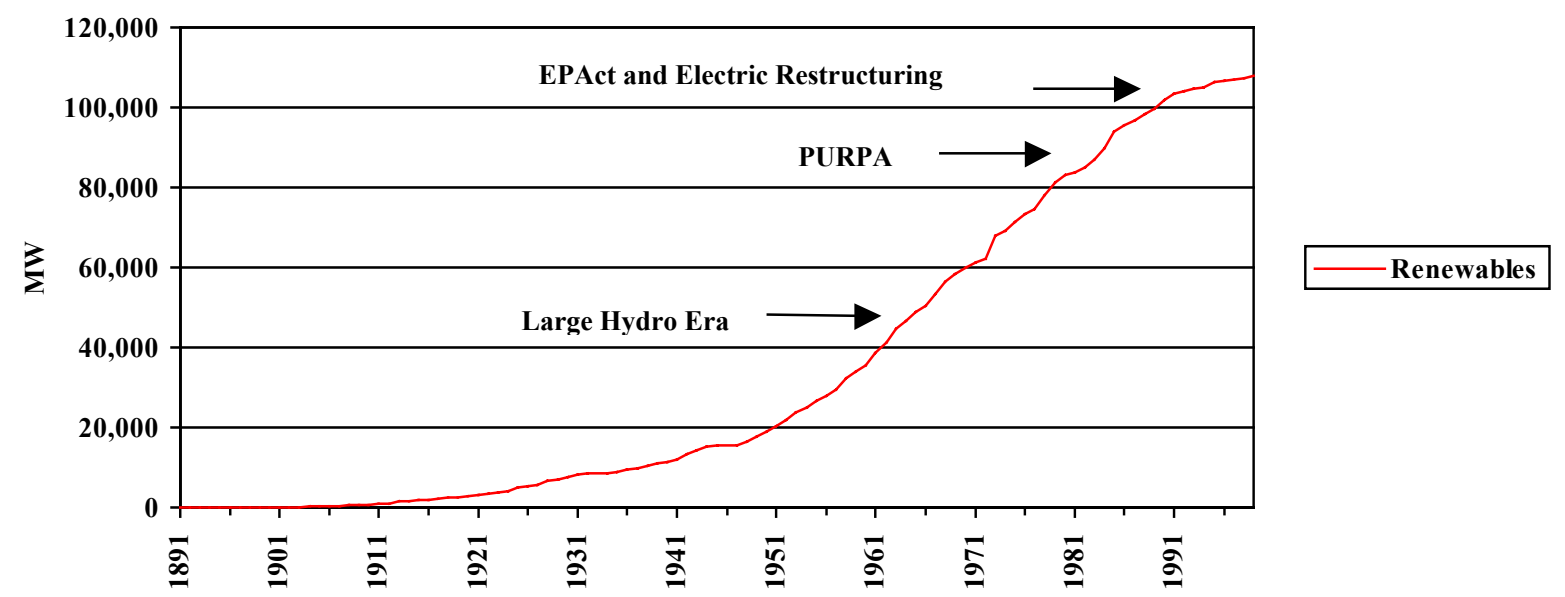

Note: Figure 1 does not include 3,042 MW of operating renewable electric capacity in REPiS that does not have an identified on-line date. 


\section{Operating Renewable Electric Plants by Technology}

\section{Biomass}

In REPiS, biomass encompasses agricultural residues, biogas, municipal solid waste, and wood residues. REPiS focuses on biomass electric technologies, but only about one-third of the 1,000 biomass-fired plants in the United States generate electricity for sale (Bain 1993). The rest are owned by the paper and wood-product industries for their own steam and electric needs. Table 4 presents the number of units and installed capacity for operating biomass electric plants, by fuel source.

Table 4. Operating Units and Capacity (kW) in REPiS of Biomass, by Fuel Source

\begin{tabular}{|l|c|r|}
\hline \multicolumn{1}{|c|}{ Biomass Fuel Source } & No. of Units & Capacity (kW) \\
\hline Agricultural Waste & 31 & 357,773 \\
\hline Biogas & 263 & $1,063,949$ \\
\hline Municipal Solid Waste & 129 & $2,563,038$ \\
\hline Wood Residues & 312 & $6,584,827$ \\
\hline Total & 735 & $10,569,588$ \\
\hline
\end{tabular}

Agricultural Waste: There are a total of 58 agricultural waste units in REPiS for a total capacity of 723 MW. Table 5 illustrates the status of this capacity.

Table 5. Summary of Agricultural Waste Capacity in REPiS, by Current Status

\begin{tabular}{|l|c|c|}
\hline Status & No. of Units & Capacity (kW) \\
\hline Operational & 31 & 357,773 \\
\hline Retired & 25 & 358,212 \\
\hline Planned & 1 & 7,800 \\
\hline Unknown & 1 & 90 \\
\hline Total & 58 & 723,875 \\
\hline
\end{tabular}

Agricultural waste facilities tend to come in two types: smaller (and typically older) plants tied to industrial or agricultural company operations, and newer and larger plants built for bulk power sales under PURPA. Agricultural waste facilities have been closing in great numbers in recent years, with 21 of the 25 retired facilities having gone out of operation since 1994. Electric utilities in California have bought out the contracts of some of these facilities, and some facilities closed because of operational problems. In Hawaii, sugar mill facilities were closed because of age and cost. 
Figure 2. Cumulative Operating Agricultural Waste Capacity by Year

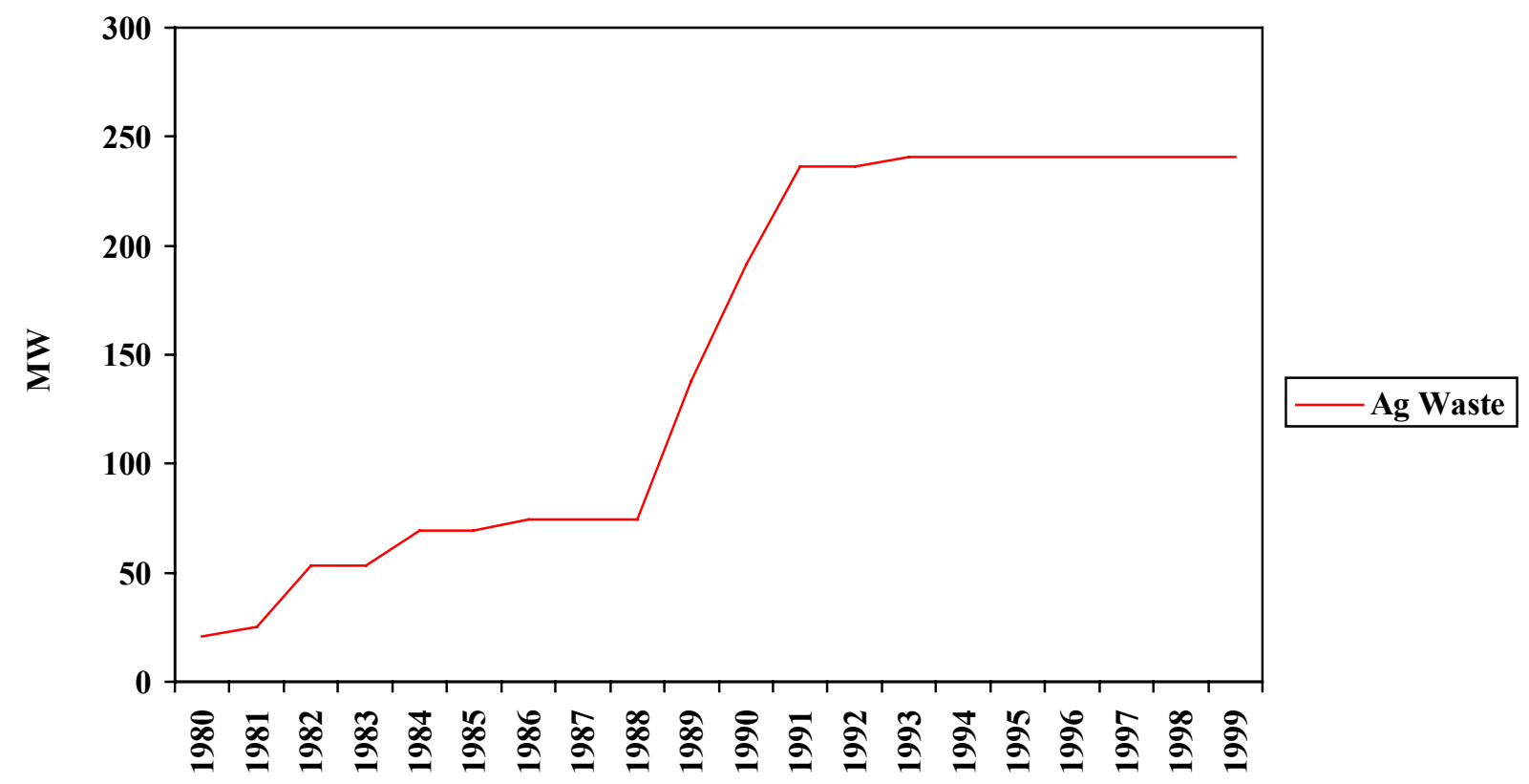

Note: Figure 2 does not include $117 \mathrm{MW}$ of agricultural waste capacity in REPiS where the on-line date is unknown.

Biogas: Biogas is defined as collecting biomass-derived gas (such as methane from landfills) and generating electricity by combusting the gas in a reciprocating engine or gas turbine. Examples of biogas fuels include bagaase, anaerobic digestion, and landfill methane. REPiS includes 357 biogas units with a total capacity of 1,344 MW. Over 300 of the 357 units in REPiS are landfill methane facilities. Table 6 represents the status of biogas facilities.

Table 6. Summary of Biogas Capacity in REPiS, by Current Status

\begin{tabular}{|l|c|c|}
\hline \multicolumn{1}{|c|}{ Status } & No. of Units & Capacity (MW) \\
\hline Operational & 263 & 1,064 \\
\hline Retired & 29 & 68 \\
\hline Planned & 53 & 196 \\
\hline Unknown & 7 & 4 \\
\hline Out of Service & 4 & 5 \\
\hline Standby & 1 & 7 \\
\hline Total & 357 & 1,344 \\
\hline
\end{tabular}

Biogas facilities are typically small - the average size of the units in REPiS is just over $3 \mathrm{MW}$. States with the greatest number of landfill methane facilities include California, Illinois, Michigan, New York, and Pennsylvania. 
Figure 3. Cumulative Operating Biogas Capacity by Year

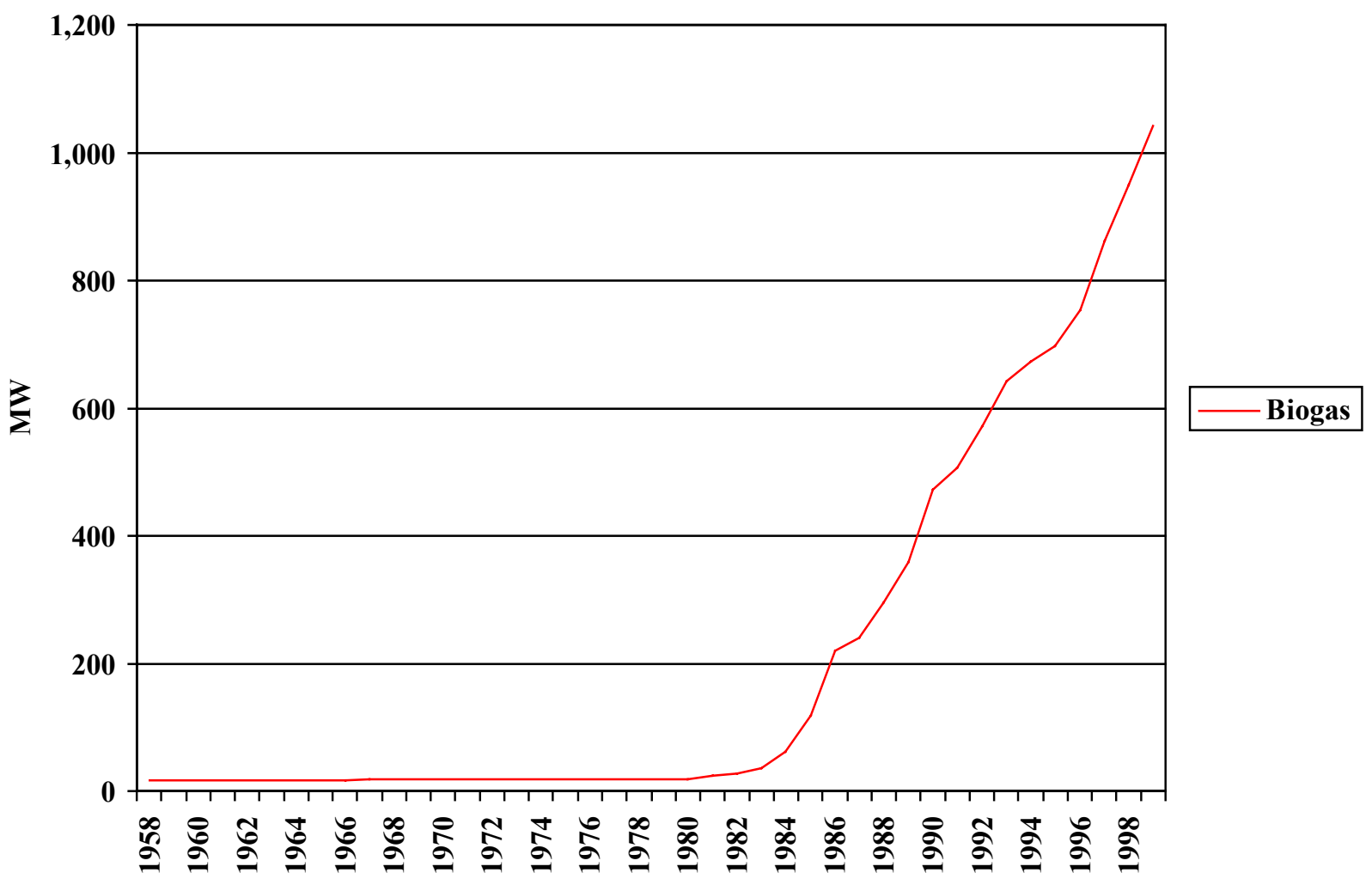

Note: Figure 3 does not include 22.445 MW of operating biogas capacity in REPiS that does not have an identified on-line date.

Landfill methane development has been driven primarily by the unconventional fuels tax credit passed as part of the Crude Oil Windfall Profits Tax of 1980. The Internal Revenue Service figured the credit annually by the price of a barrel of oil. According to some landfill gas developers, in terms of electricity production, the tax credit was worth up to 1.2 cents/kWh (Williams and Bateman 1995). The credit expired at the end of 1998 (Berenyi 1999a).

Waste-to-Energy: There are 168 waste-to-energy units in REPiS, with a total capacity of about 3,114 MW. Table 7 represents the status of (WTE) units. 
Table 7. Summary of Waste-to-Energy Capacity in REPiS, by Current Status

\begin{tabular}{|l|c|c|}
\hline \multicolumn{1}{|c|}{ Status } & No. of Units & Capacity (kW) \\
\hline Operational & 129 & 2,563 \\
\hline Retired & 34 & 477 \\
\hline Unknown & 4 & 73 \\
\hline Out of Service & 1 & 1 \\
\hline Total & 168 & 3,114 \\
\hline
\end{tabular}

Although the first waste-to-energy plants in the United States were built in the 1920s and 1930s, waste-to-energy experienced the biggest gain in the 1980s, when 72 units with a total capacity of $1,335 \mathrm{MW}$ became operational. Market activity in that decade alone represents over $50 \%$ of capacity for all operating waste-to-energy facilities in REPiS. Like most of the other renewable energy technologies, waste-to-energy benefited from five-year accelerated depreciation, business energy tax credits, and power purchase contracts under PURPA. Waste-to-energy also was often eligible for tax-exempt municipal bond financing, which facilitated the construction of a number of municipalowned waste-to-energy facilities.

Figure 4. Cumulative Operating Waste-to-Energy Capacity by Year

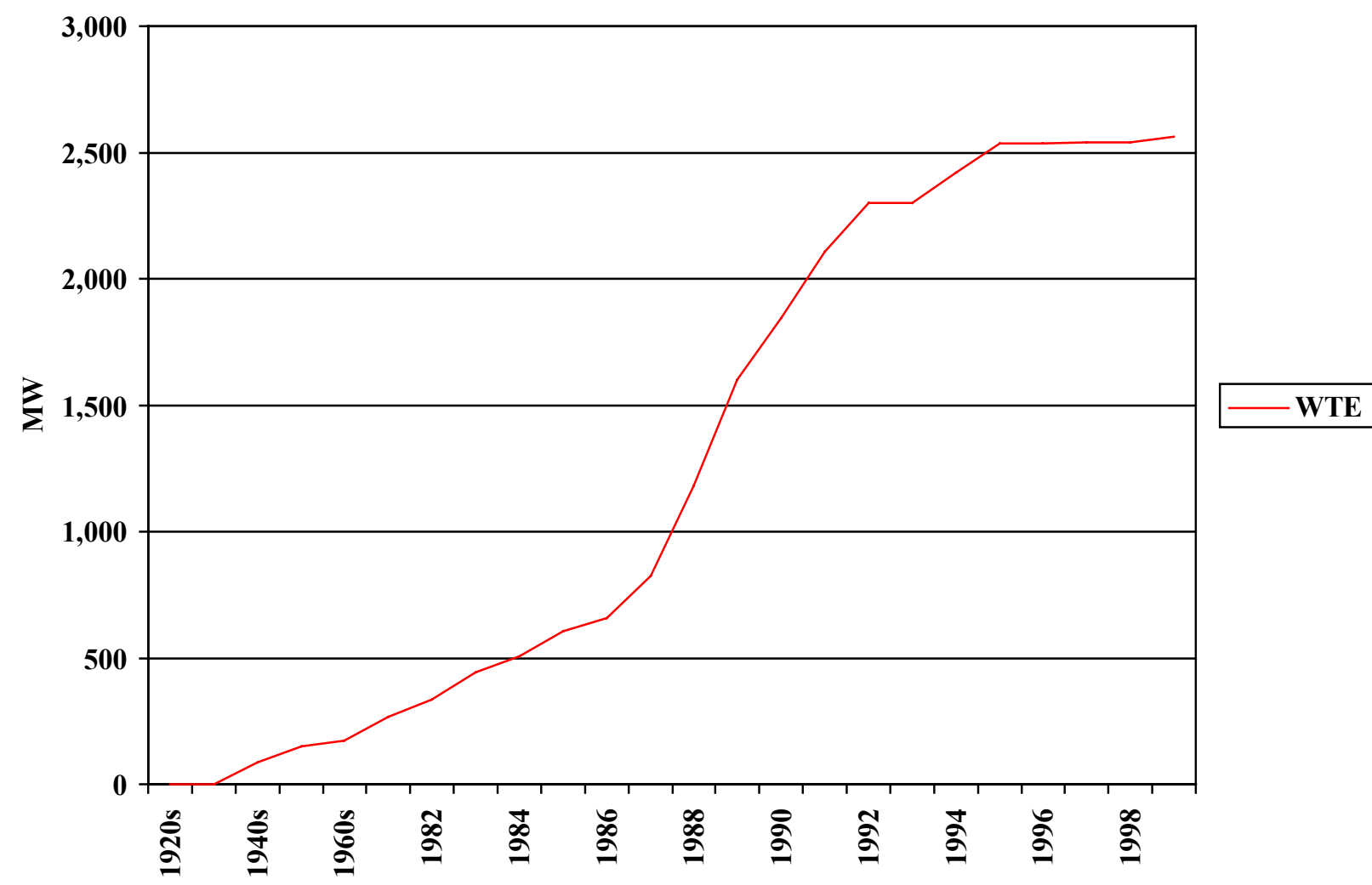


Market activity for waste-to-energy slowed precipitously in the 1990s because of the repeal of tax credits, lessened availability of power purchase contracts, sharper restrictions placed by Congress on the use of municipal tax-exempt bond financing in the 1986 Tax Reform Act, and increased public opposition to waste-to-energy facilities. In addition, a 1994 U.S. Supreme Court decision struck down the ability of municipal and county government to direct the flow of municipal solid waste towards municipal landfills or municipal waste-to-energy facilities, meaning waste-to-energy plants no longer had a predictable flow of waste and/or revenues to rely on. There were 33 waste-toenergy facilities that became operational in the 1990s that are still operating, for a total of $960 \mathrm{MW}$. Of these, only five came on-line after 1994. In addition, of the 34 waste-to-energy facilities in REPiS that are retired, 18 of these facilities, representing $395 \mathrm{MW}$, retired in the 1990s because of economic and/or operating problems.

Wood Residues: There are 382 wood residue units in REPiS with a total capacity of over 7,204 MW. Table 8 represents the status of wood residue units.

Table 8. Summary of Wood Residue Capacity in REPiS, by Current Status

\begin{tabular}{|l|c|c|}
\hline \multicolumn{1}{|c|}{ Status } & No. of Units & Capacity (kW) \\
\hline Operational & 312 & $6,584,828$ \\
\hline Retired & 55 & 477,211 \\
\hline Planned & 4 & 68,800 \\
\hline Unknown & 9 & 64,700 \\
\hline Standby & 2 & 8,625 \\
\hline Total & 382 & $7,204,164$ \\
\hline
\end{tabular}

Wood residue facilities are generally not new - the on-line date of the oldest operating wood residue facility in REPiS is 1906. Wood residues have also been co-fired with fossil fuels, by electric utilities and other companies-REPiS includes data on six utility fossil plants that co-fire a small amount of wood residues, for a total wood residue capacity in this application of $71 \mathrm{MW}$.

Wood residue capacity almost doubled in the 1980s because of tax incentives and favorable power purchase contracts. Total wood residue capacity in the United States peaked in 1997 and has largely remained flat since. Planned facilities in 2000 and 2002 will increase wood residue capacity slightly. 
Figure 5. Cumulative Operating Wood Residue Capacity by Year

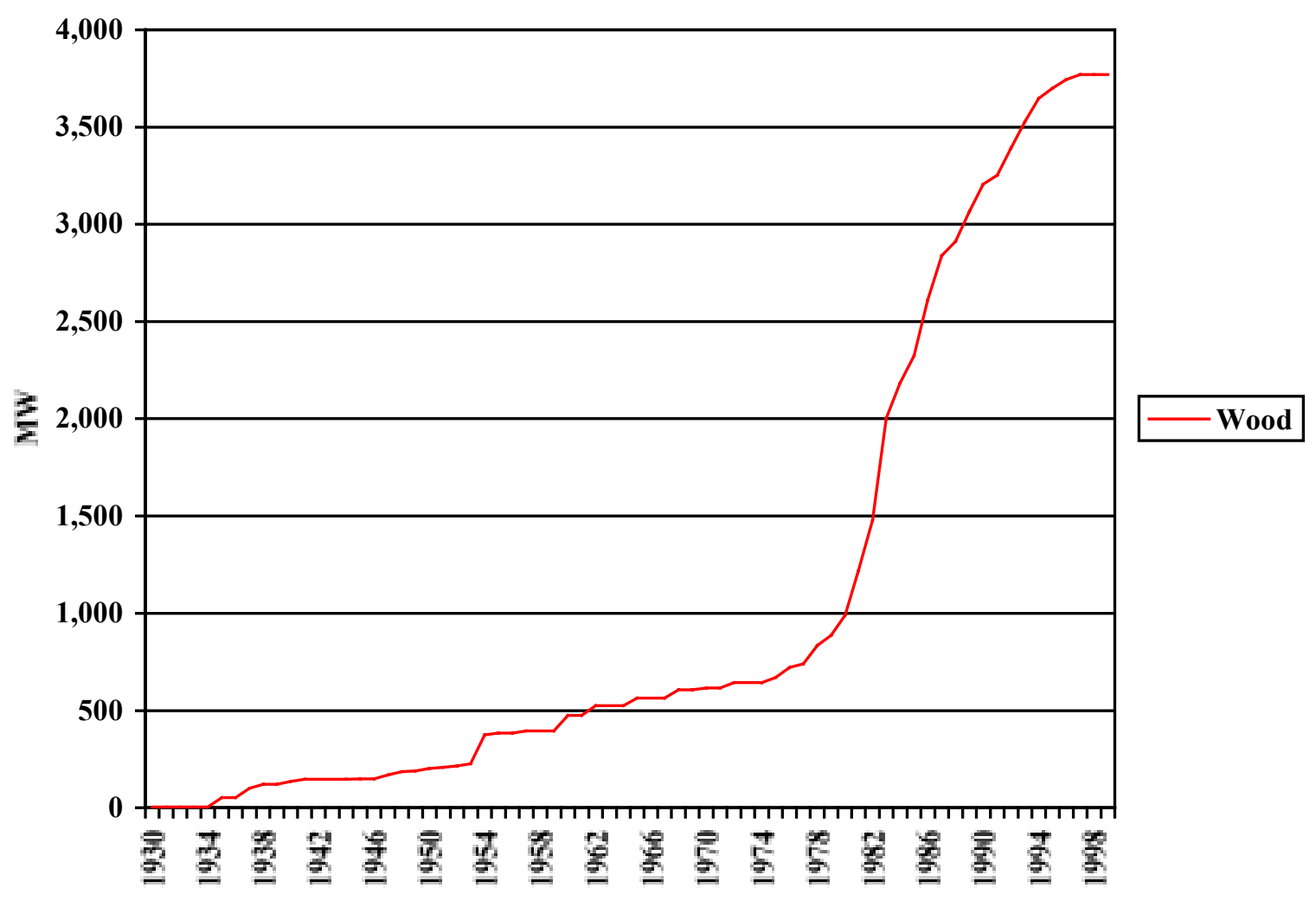

Note: Figure 5 does not include 2,816.5 MW of operating wood residue facilities in REPiS that do not have an identified on-line date.

As in the case of waste-to-energy, the 1990s have been a period of low market activity for wood residues, a time when several plants went out of service, either because of poor economics, or electric utilities buying out the power purchase contracts. There were 44 wood residue units that retired in the 1990s, representing almost 383 MW.

Geothermal: There are 140 geothermal units in REPiS, with a total capacity of almost 3,648 MW. Table 9 shows the current status of geothermal capacity.

Table 9. Summary of Geothermal Capacity in REPiS, by Current Status

\begin{tabular}{|l|c|c|}
\hline \multicolumn{1}{|c|}{ Status } & No. of Units & Capacity (kW) \\
\hline Operational & 105 & $2,697,150$ \\
\hline Retired & 19 & 398,120 \\
\hline Planned & 10 & 225,499 \\
\hline Unknown & 5 & 272,000 \\
\hline Out of Service & 1 & 55,000 \\
\hline Total & 140 & $3,647,769$ \\
\hline
\end{tabular}


Operating geothermal plants tend to be divided between the larger geothermal units built at The Geysers in California, ranging from 100-120 MW, and smaller facilities under the statutory maximum of $80 \mathrm{MW}$ that were developed under PURPA. Geothermal power had steady growth through the 1980s, with 52 units and $607 \mathrm{MW}$ coming on-line between 1987 and 1989 alone. That steady growth did not persist into the 1990s, with only about $185 \mathrm{MW}$ being developed in that decade, and no new development since 1996. About $150 \mathrm{MW}$ of geothermal power is scheduled for development in California by 2002, using that state's systems benefit charge for renewable energy technologies.

The geothermal industry has also undergone some consolidation, and many geothermal companies sold their assets during the 1990s. In addition, Pacific Gas \& Electric (PG\&E) sold its Geysers geothermal facilities to Calpine Corporation in 1999 to comply with state restructuring legislation requiring that electric utilities sell their generating assets.

Figure 6. Cumulative Operating Geothermal Capacity by Year

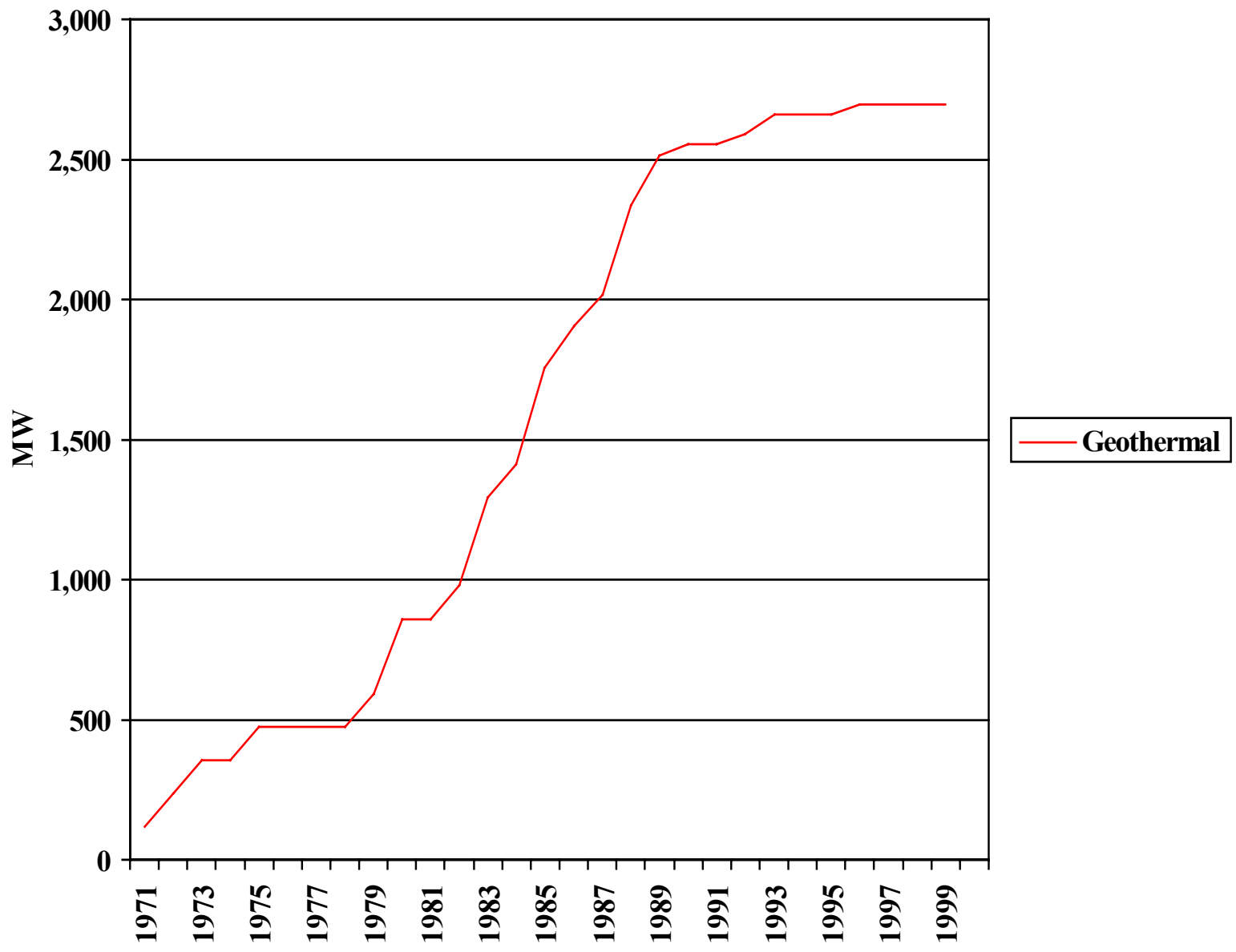

Hydro: There are 5,198 hydro units in REPiS with a total capacity of more than 96,456 MW. Pumped storage hydro accounts for $19,646 \mathrm{MW}$ of this total hydro capacity in REPiS. Table 10 presents the operational status of hydro capacity. 
Table 10. Summary of Hydro Capacity in REPiS, by Current Status

\begin{tabular}{|l|c|c|}
\hline \multicolumn{1}{|c|}{ Status } & No. of Units & Capacity (kW) \\
\hline Operational & 4,731 & $94,789,367$ \\
\hline Retired & 282 & 414,362 \\
\hline Planned & 41 & 579,910 \\
\hline Unknown & 112 & 406,243 \\
\hline Out of Service & 29 & 109,624 \\
\hline Testing & 2 & 156,760 \\
\hline Standby & 1 & 500 \\
\hline Total & 5,198 & $96,456,766$ \\
\hline
\end{tabular}

The first hydro plant to produce electricity was built in 1880 in Grand Rapids, Michigan (Hydro Review 1997). Soon after the turn of the century, hydro accounted for $15 \%$ of the generating capacity in the United States, about half of which was installed at industrial facilities. Higher demand for electricity caused hydro capacity to triple between 1920 and 1940, and hydro accounted for $30 \%$ of the nation's generating capacity in the 1930s. Hydro capacity tripled again between 1940 and 1960, when government agencies such as the U.S. Army Corp of Engineers and the Bureau of Reclamation built many large dams around the country (Federal Energy Regulatory Commission [FERC] 1992).

After 1960, the construction of large hydro plants slowed because of the availability of inexpensive coal and other fossil fuels and fewer available hydro sites. The passage of PURPA in 1978 and various federal tax incentives helped stimulate the development of small hydro facilities in the 1980s. These tax incentives expired in 1988. The passage of the Electric Consumers Protection Act of 1986 gave states and private intervenors greater ability to intervene in FERC's hydro licensing process. This increased the costs of licensing for hydro developers, just as fossil fuel costs were declining, and the availability of power purchase contracts was also decreasing (Williams and Bateman 1995). As a result, hydro development slowed in the late 1980s and in the 1990s. Indeed, the 6,150 MW of hydro capacity that came on-line in the 1990s, according to REPiS data, is the lowest amount of hydro capacity to come on-line in any decade since the 1930s. Still, hydro capacity generally increases a little each year, and there is almost $580 \mathrm{MW}$ of planned hydro capacity in REPiS. 
Figure 7. Cumulative Operating Hydro Capacity by Year

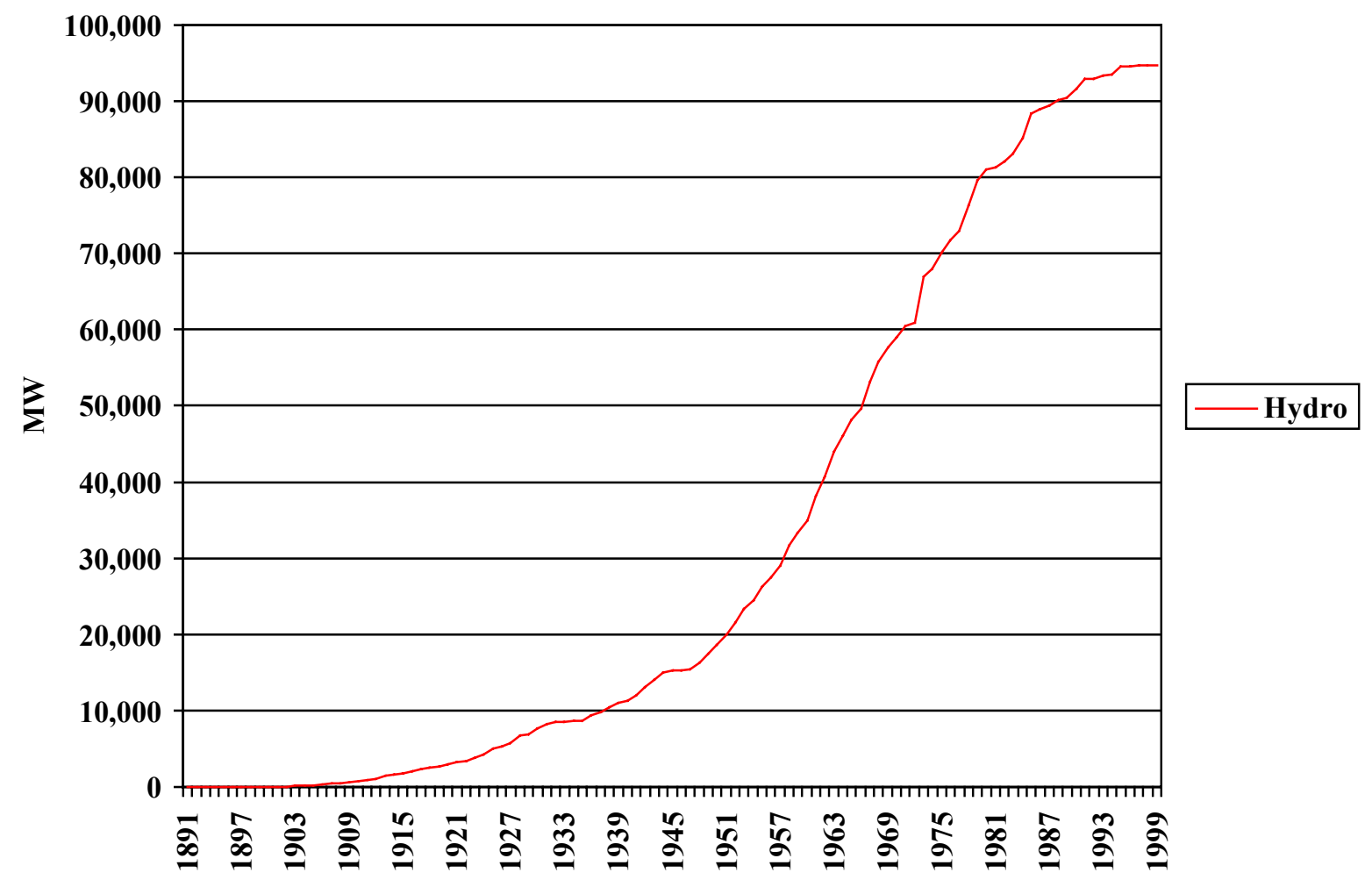

Note: Figure 7 does not include 27 MW of operating hydro capacity in REPiS without an identified on-line date.

Photovoltaics: REPiS has 866 PV units for a total capacity of almost 90 MW. Table 11 gives the current status of photovoltaics capacity.

Table 11. Summary of Photovoltaics Capacity in REPiS, by Current Status

\begin{tabular}{|l|c|c|}
\hline \multicolumn{1}{|c|}{ Status } & No. of Units & Capacity (kW) \\
\hline Operational & 688 & $15,431.5$ \\
\hline Retired & 72 & $7,561.6$ \\
\hline Planned & 98 & $66,772.8$ \\
\hline Unknown & 5 & 116.5 \\
\hline Out of Service & 3 & 3.3 \\
\hline Total & 866 & $89,885.71$ \\
\hline
\end{tabular}

In the 1980s, PV demonstration systems of one MW and higher were installed by government, electric utilities, and private entities to test the performance and feasibility of these systems. Most of these systems are no longer in operation, either because the testing period concluded or the company involved decided to exit the PV business. 
Figure 8. Cumulative Operating Photovoltaics Capacity by Year

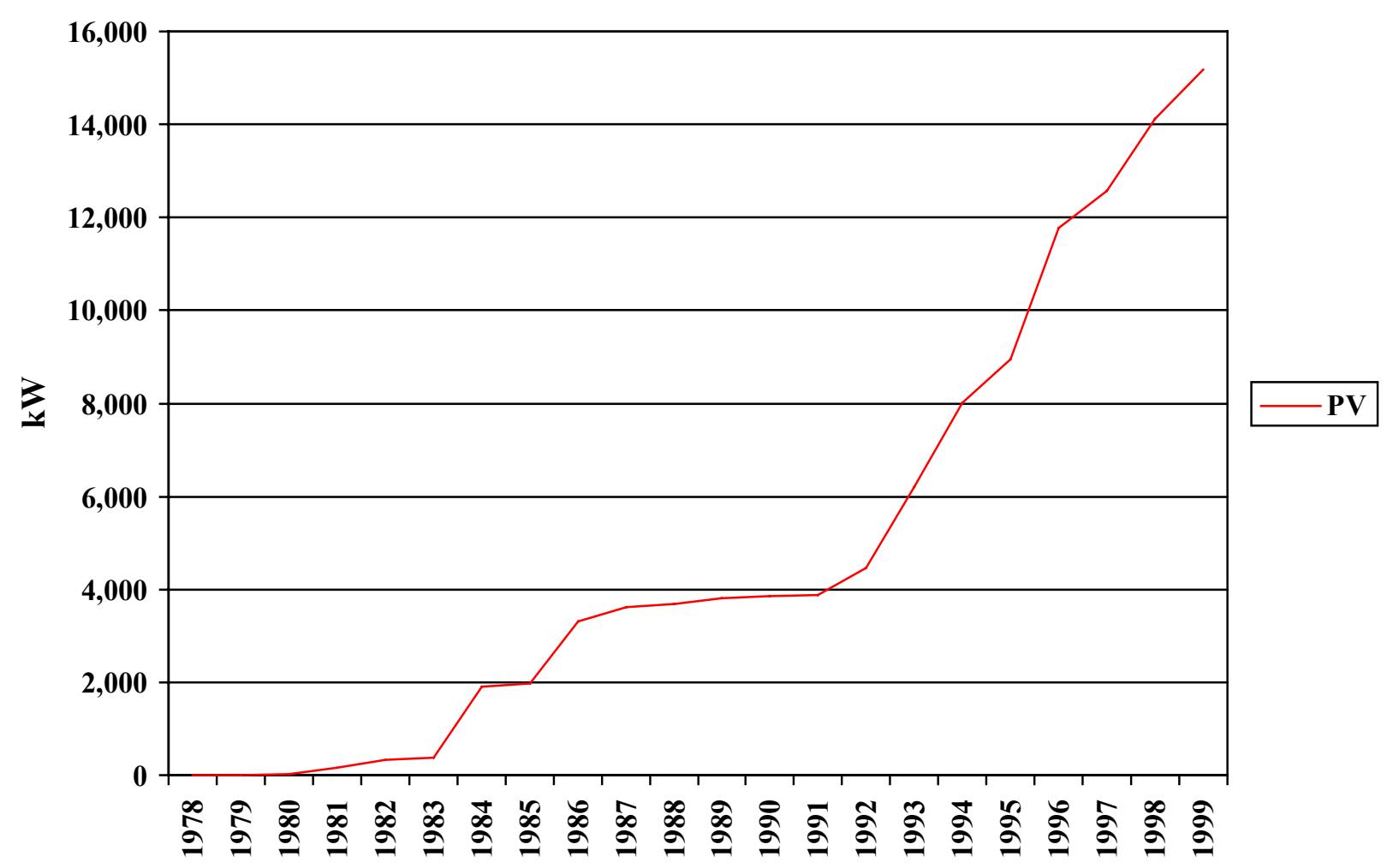

Note: Figure 8 does not include $255 \mathrm{~kW}$ of operating PV capacity in REPiS that does not have an identified on-line date.

In recent years, more numerous but much smaller PV systems have been installed. Improving economics has made PV cost effective for a number of on-grid and off-grid niche applications. President Clinton also announced in 1997 an initiative to install a million solar roofs by 2010 through public-private partnerships. In addition, the Utility Photovoltaic Group has sponsored several utility PV installations through public-private partnerships with the U.S. Department of Energy (DOE). Individual utilities have also aggressively installed PV systems. One notable example is the Sacramento Municipal Utility System (SMUD), which has installed 7 MW of PV systems and plans to install $10 \mathrm{MW}$ more by 2003 (Osborn 2000). As a result, there were more than 400 units of PV installed between 1993 and 1999_more than twice the number installed before 1993.

Solar Thermal: REPiS has 22 solar thermal electric units for a total of $371 \mathrm{MW}$. Table 12 provides a summary of solar thermal electric capacity. 
Table 12. Summary of Solar Thermal Electric Capacity in REPiS, by Current Status

\begin{tabular}{|l|c|c|}
\hline \multicolumn{1}{|c|}{ Status } & No. of Units & Capacity (kW) \\
\hline Operational & 14 & 353,925 \\
\hline Retired & 6 & 15,575 \\
\hline Planned & 1 & 2,000 \\
\hline Unknown & 1 & 7.5 \\
\hline Total & 22 & 371,508 \\
\hline
\end{tabular}

Most of the operating solar thermal electric plants, and almost all of the operating capacity, are from the parabolic trough plants developed by Luz International in the 1980s. The company developed eight such plants in southern California before the removal of various state and federal tax incentives prompted the company to cease operations in 1991. All eight of the plants Luz International developed are still in operation. Today, activity in solar thermal electric is mostly limited to research and development to reduce costs, and field tests and demonstrations. These include small parabolicdish plants that some believe could be well positioned to take advantage of increasing interest in distributed power markets.

Figure 9. Cumulative Operating and Planned Solar Thermal Capacity by Year

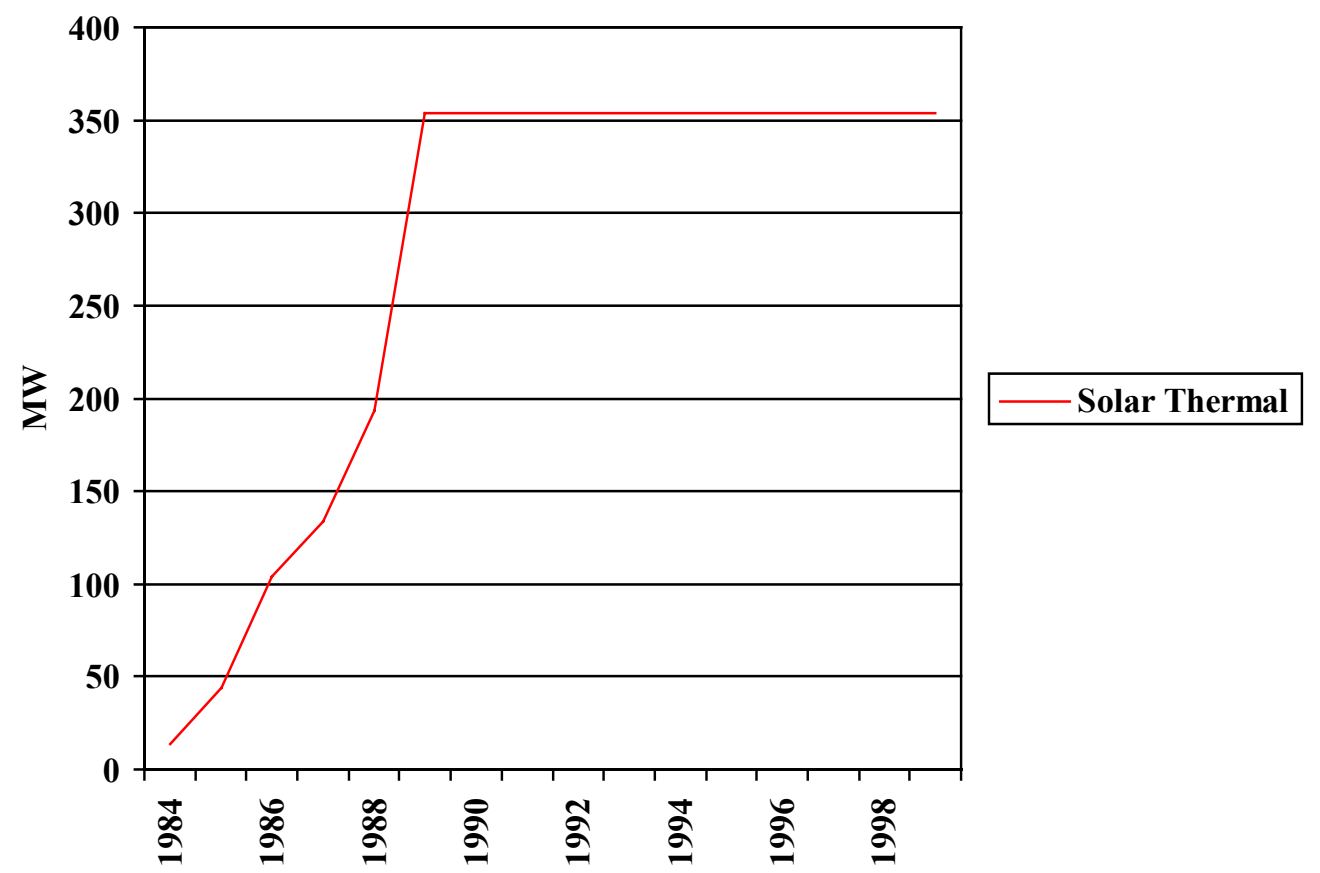

Wind: There are 1,002 wind energy units in REPiS for a total capacity of almost 4,274 MW. Table 13 represents the current status of wind energy capacity. This data includes individual wind turbine installations as well as utility-scale wind power facilities. 
Table 13. Summary of Wind Energy Capacity in REPiS, by Current Status

\begin{tabular}{|l|c|c|}
\hline \multicolumn{1}{|c|}{ Status } & No. of Units & Capacity (MW) \\
\hline Operational & 546 & 2,602 \\
\hline Retired & 238 & 302 \\
\hline Planned & 43 & 1,174 \\
\hline Unknown & 169 & 170 \\
\hline Out of Service & 6 & 25 \\
\hline Total & 1,002 & 4,273 \\
\hline
\end{tabular}

Wind turbines have been used for years in the United States for water pumping and non-grid and grid-connected residential applications. Interest in larger wind turbines for electric power generation

Figure 10. Cumulative Operating and Planned Wind Energy Capacity by Year

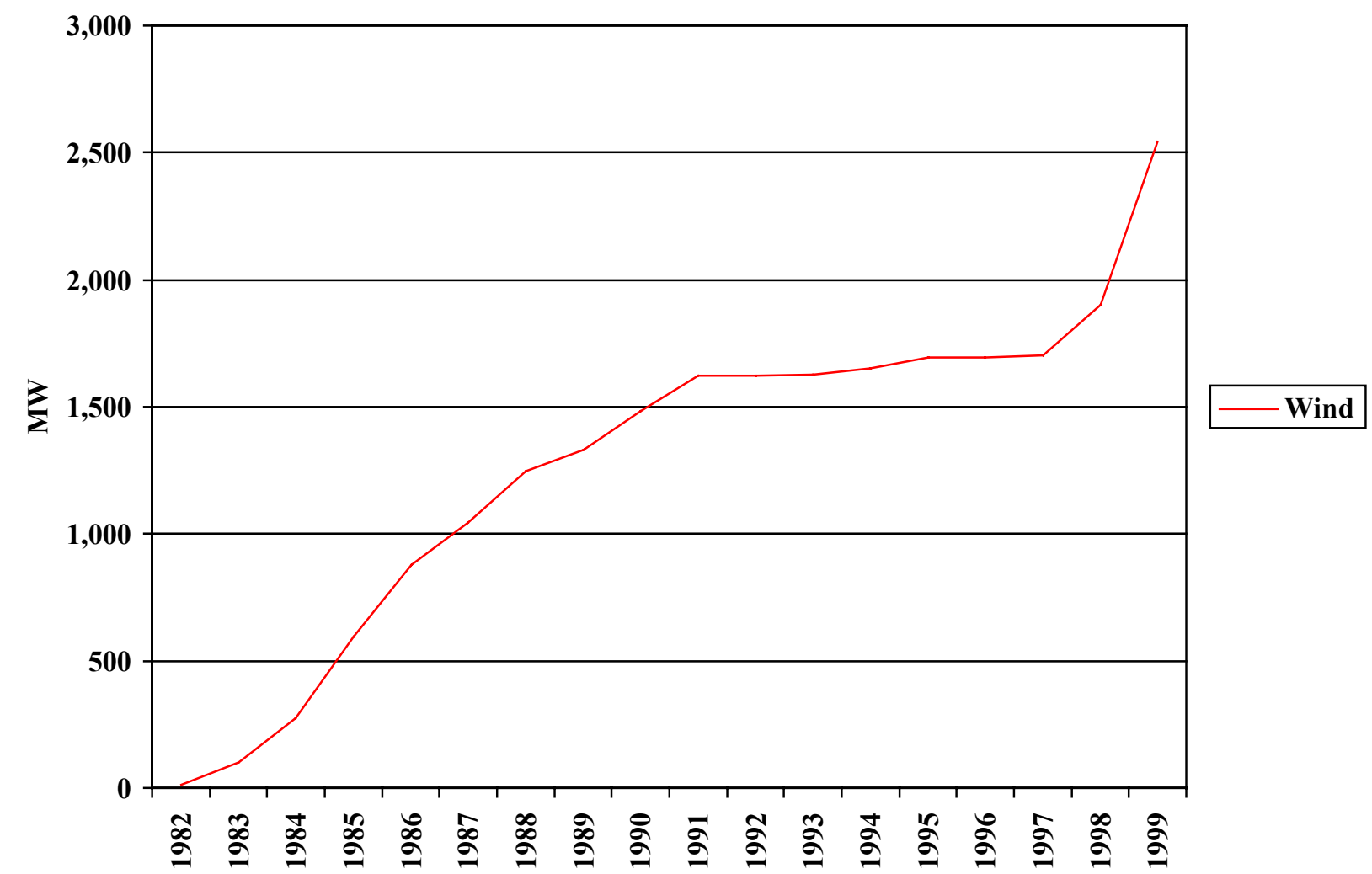

Note: Figure 10 does not include $58 \mathrm{MW}$ of operating wind capacity in REPiS that does not have an identified on-line date.

increased in the 1980s with the onset of federal and state tax incentives, and the enactment of PURPA. The data in REPiS show that installed wind capacity, starting from near zero in the early 1980s, reached 1,388 MW by 1989, with almost all of this capacity located in California. The 
expiration of tax incentives in 1985 and lower fossil fuel prices resulted in a relatively stagnant market for wind in the early-to-mid 1990s. A production tax credit (PTC) included in the Energy Policy Act of 1992 (EPAct), and continuing cost declines and performance improvements sparked some new interest in wind, with installed capacity reaching $1,960 \mathrm{MW}$ by 1998 . A combination of improved market conditions, state policy mandates, and the scheduled expiration of the PTC (since extended through 2001) resulted in almost $700 \mathrm{MW}$ of new wind capacity added in 1999, according to data in REPiS. Wind development has also moved beyond California to encompass over 20 states, and more than $1,100 \mathrm{MW}$ of wind is in various stages of planning.

\section{Planned Renewable Energy Units}

To the extent available, data were collected on planned units for REPiS, defined in REPiS as renewable energy units that would begin operating in 2000 or later. Data sources for planned units are incomplete, and the data in REPiS probably does not capture the universe of planned gridconnected renewable energy units. Therefore, the planned data in REPiS should be viewed as illustrative, not comprehensive. There are about 250 planned units representing about 2,300 MW of capacity by 2013. Figure 11 shows this data graphically. These numbers are down from the 1994 edition of REPiS, which included 257 planned units and a total capacity of almost 8,000 MW.

Figure 11. Planned Renewable Electric Capacity by Year Expected On-Line (MW)

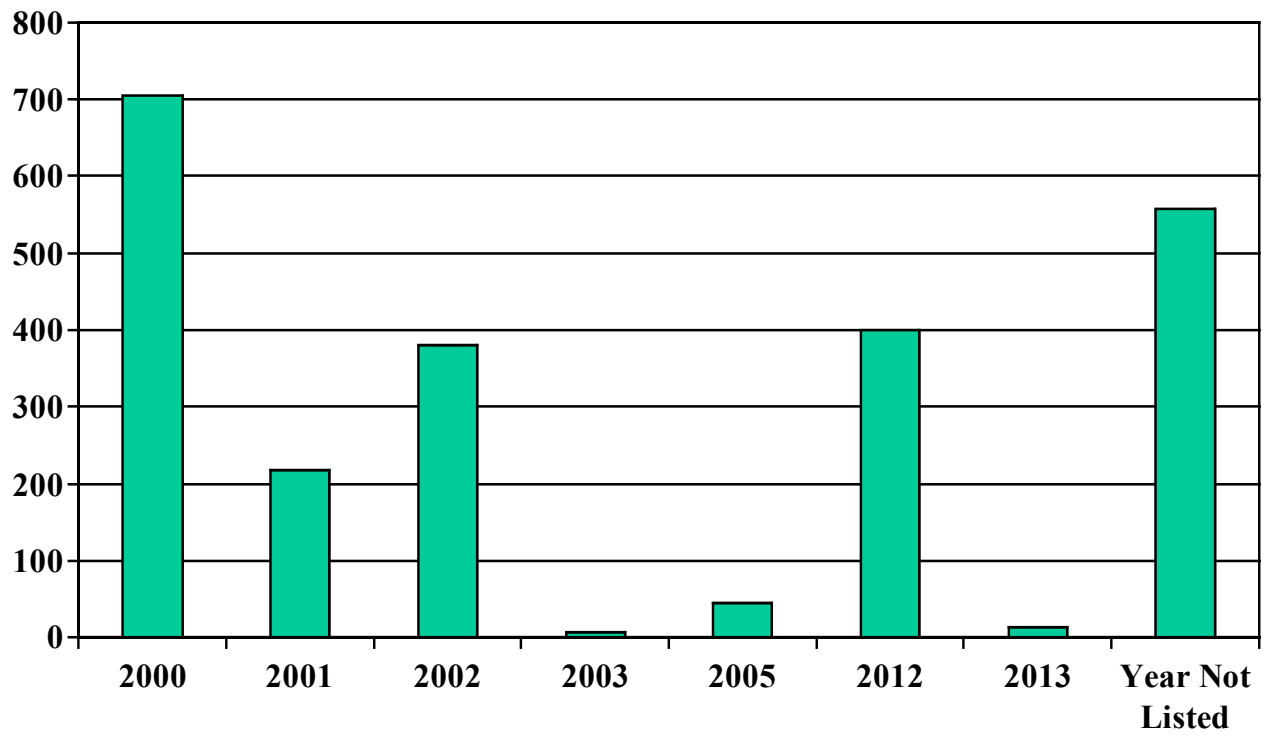

All of the renewable electric technologies had less planned capacity than in the 1994 edition of REPiS, sometimes sharply so (see Table 14). Some of the decline is partly due to tighter market conditions and uncertainty over electric restructuring; however, it may also be due to developers keeping project development plans confidential as the generation market becomes more competitive. In addition, renewable energy policies such as the renewables portfolio standard (RPS) and the systems benefit charge (SBC) will create some new renewable electric power plants (Wiser, Porter, 
and Clemmer 2000). These policies are only partially reflected in REPiS because, for the most part, these policies are not fully implemented yet. REPiS does capture some state renewable policies if they are technology specific. An example is the Minnesota Public Utility Commission's 1998 order to Northern States Power to competitively bid for an additional 400 MW of wind by 2012.

A probability-of-success variable was not assigned to planned units. Unlike the previous edition of REPiS, this edition of REPiS treats all planned units as equally likely to be developed. For this reason, some caution should be used in interpreting aggregate data on planned renewable electric units, as unexpected developments may prevent these planned units from coming on-line. This is even more true as the electric power market evolves into a more "merchant-style" environment, in which plant developers build an electric facility with customers for only some, or even none, of the plant's output. For instance, American National Power brought a 30-MW wind plant on-line in Texas in 1999, and announced plans to develop $250 \mathrm{MW}$ more if warranted by market conditions. That planned facility is listed in REPiS, even though there is no projected on-line date, and future market conditions may not allow the company to go forward with the plant. Conversely, some planned hydro facilities have been in planning for several years, in part because of the difficulties in siting and receiving state and federal permits.

Wind leads all the renewable electric technologies with 1,174 MW of planned capacity, followed by biomass with $272 \mathrm{MW}$ and geothermal with $225 \mathrm{MW}$. Improved economics, the production tax credit, and some favorable state policies explain why wind is doing better than the other renewable energy technologies. Photovoltaics has a sharp increase in the number of units in this edition of REPiS, from 11 to 98 , although the small size of each unit keeps the overall planned capacity at 66.7 MW.

Table 14. Planned Renewable Units and Capacity by Technology by REPiS Edition

\begin{tabular}{|l|c|c|c|c|}
\hline Technology & No. of Units & Capacity (kW) & $\begin{array}{c}\text { No. of Units } \\
\text { 1994 Edition }\end{array}$ & $\begin{array}{c}\text { Capacity (kW) } \\
\text { 1994 Edition }\end{array}$ \\
\hline Biomass & 58 & 272,496 & 86 & $1,142,650$ \\
\hline Geothermal & 10 & 225,499 & 21 & 710,000 \\
\hline Hydro & 41 & 579,910 & 87 & $4,147,412$ \\
\hline Photovoltaics & 98 & 66,733 & 11 & 105,500 \\
\hline Solar Thermal & 1 & 2,000 & 3 & 10,015 \\
\hline Wind & 43 & $1,174,060$ & 49 & $1,842,305$ \\
\hline Total & 251 & $2,320,698$ & 257 & $7,957,882$ \\
\hline
\end{tabular}

\section{Leading States in Renewable Energy Capacity Development}

Table 15 presents the leading states in the amount of operating renewable energy capacity. Washington has the most renewable energy capacity, all but $305 \mathrm{MW}$ from hydro. California is next, followed by Oregon, New York, Tennessee, Georgia, South Carolina, Alabama, Virginia, and Arizona. 
Table 15. States with the Most Operating Renewable Energy Capacity in REPiS

\begin{tabular}{|l|c|}
\hline \multicolumn{1}{|c|}{ State } & Renewable Energy Capacity (kW) \\
\hline Washington & $20,988,683$ \\
\hline California & $18,687,494$ \\
\hline Oregon & $8,502,366$ \\
\hline New York & $6,006,570$ \\
\hline Tennessee & $3,965,238$ \\
\hline Georgia & $3,769,458$ \\
\hline South Carolina & $3,741,574$ \\
\hline Alabama & $3,603,450$ \\
\hline Virginia & $3,507,662$ \\
\hline Arizona & $2,993,958$ \\
\hline
\end{tabular}

Table 16 lists the states with the most operating non-hydro renewable electric capacity. Excluding hydro markedly changes the state capacity rankings, as compared to Table 15 . Of the 10 states in Table 15, only Alabama, California, Georgia, and New York also rank high with non-hydro renewable energy capacity.

\section{Table 16. States with the Most Operating Non-Hydro Renewable Energy Capacity in REPiS}

\begin{tabular}{|l|c|}
\hline \multicolumn{1}{|c|}{ State } & Renewable Energy Capacity (kW) \\
\hline California & $5,498,537$ \\
\hline Florida & $1,024,607$ \\
\hline Maine & 756,405 \\
\hline Alabama & 743,780 \\
\hline Minnesota & 530,122 \\
\hline Louisiana & 524,600 \\
\hline Michigan & 483,845 \\
\hline New York & 471,361 \\
\hline Georgia & 458,979 \\
\hline Texas & 433,627 \\
\hline
\end{tabular}

Planned renewable units are found in 41 states, representing a total of 2,320 MW. This compares to 36 states in the 1994 edition of REPiS; however, that edition of REPiS showed more planned capacity, at 7,957 MW. Table 17 below lists the five states with the most planned renewable energy capacity. See Table A-2 in the Appendix for a list of states with planned renewable energy capacity. 
Table 17. States with the Most Planned Renewable Energy Capacity

\begin{tabular}{|l|c|}
\hline \multicolumn{1}{|c|}{ State } & Capacity (kW) \\
\hline California & 587,479 \\
\hline Minnesota & 490,002 \\
\hline Nevada & 259,999 \\
\hline Texas & 231,013 \\
\hline Alaska & 144,960 \\
\hline
\end{tabular}

\section{Comparison to the 1994 Edition of REPiS}

There was a 7\% increase in operating renewable electric capacity in REPiS between 1994 and 1999 (see Table 18 below). Although some of this was due to more renewables capacity coming on-line, some of it is due to improved data sources in this version of REPiS.

Biomass experienced the greatest growth of any technology in REPiS, an increase of as much as $85 \%$ from the previous edition of REPiS, or $17 \%$ annually. This is primarily because better data sources were available that captured more of the operating biomass power plants than previous data sources. Specifically, the California Biomass Energy Alliance published a directory of biomass facilities in 1998 that included several wood residue plants that were not included in REPiS (Reese 1998). Concerning other renewable energy technologies, photovoltaics had growth of $75 \%$ (15\% annually), which is likely due to the success of several public-private partnerships. Geothermal and solar thermal had slight decreases in capacity because of a change in defining installed capacity in REPiS from gross capacity to net capacity.

Table 18. Comparison in Capacity (kW) Between REPiS III and REPiS IV, by Technology

\begin{tabular}{|l|r|r|r|r|r|r|r|}
\hline & \multicolumn{1}{l|}{ Biomass } & \multicolumn{1}{l|}{ Geothermal } & \multicolumn{1}{l|}{ Hydro* } & \multicolumn{1}{l|}{ PV } & $\begin{array}{l}\text { Solar } \\
\text { Thermal }\end{array}$ & \multicolumn{1}{l|}{ Wind } & \multicolumn{1}{l|}{ Total } \\
\hline REPiS III & $5,739,215$ & $2,904,858$ & $92,671,697$ & 8,778 & 367,748 & $2,154,354$ & $103,846,650$ \\
\hline REPiS IV & $10,658,887$ & $2,697,150$ & $94,789,367$ & 15,432 & 353,925 & $2,601,695$ & $111,116,455$ \\
\hline Net & $4,919,672$ & $-207,708$ & $2,117,670$ & 6,654 & $-13,823$ & 447,341 & $7,269,805$ \\
\hline \% Change & 85.72 & -7.15 & 2.29 & 75.80 & -3.76 & 20.76 & 7.00 \\
\hline
\end{tabular}

* Includes pumped storage hydro.

Table 19 presents a comparison between the data in REPiS, and utility and non-utility renewable electric technology data collected by EIA (EIAa 1999). Overall, there is slightly less renewables capacity in REPiS than in EIA's data, but there are substantial differences by renewable energy technology. For example, REPiS has about three times as much photovoltaics capacity as EIA does-EIA does not collect data on facilities under one MW, whereas REPiS has no such distinction. REPiS also has more data on wind capacity, but that may be a function of publication rather than data completeness. EIA's most recent report does not capture the $700 \mathrm{MW}$ of wind that became operational in 1999 to take advantage of the then-expiring production tax credit. REPiS has less renewables electric capacity than EIA in geothermal, hydro, and solar thermal. 
Table 19. Comparison in Capacity (kW) Between EIA and REPiS, by Technology

\begin{tabular}{|l|r|r|r|r|r|r|r|}
\hline & \multicolumn{1}{|l|}{ Biomass } & \multicolumn{1}{l|}{ Geothermal } & Hydro* & \multicolumn{1}{l|}{ PV } & $\begin{array}{l}\text { Solar } \\
\text { Thermal }\end{array}$ & \multicolumn{1}{l|}{ Wind } & \multicolumn{1}{l|}{ Total } \\
\hline EIA (1998)** & $10,374,000$ & $2,999,000$ & $98,559,000$ & 5,000 & 385,000 & $1,689,000$ & $114,011,000$ \\
\hline REPiS IV & $10,658,887$ & $2,697,150$ & $94,789,367$ & 15,432 & 353,925 & $2,601,695$ & $111,116,455$ \\
\hline Net & 284,887 & $-301,850$ & $-3,769,633$ & 10,432 & $-31,075$ & 912,695 & $-2,894,545$ \\
\hline \% Difference & 2.75 & -10.07 & -3.82 & 208.64 & -8.07 & 54.04 & -2.54 \\
\hline
\end{tabular}

* Includes pumped storage hydro.

** Source: Energy Information Administration. Electric Power Annual 1998, Vol. II, DOE-EIA-0348(2), Table 1, pp. 12-13.

\section{Implications for REPiS from Electric Restructuring}

Electric restructuring was just emerging when the 1994 edition of REPiS was released in 1995. At the time, only California and Rhode Island had started to restructure their electric power sector, and no electric utility had sold off its generating facilities, either voluntarily or under state order. Since then, more than 20 states have passed electric restructuring legislation or regulatory orders, and several utilities have divested their generation facilities to non-utility parties. Almost all of the renewable electric facilities divested by electric utilities have been hydro facilities - the notable exceptions include PG\&E's geothermal facilities at The Geysers, and a geothermal plant owned by SMUD.

Electric restructuring will change the way data on electric power are collected. Data availability will be more restricted, especially commercially sensitive data such as capital cost and plant operation and maintenance costs. Several electric utilities have objected that the data they file with the Federal Energy Regulatory Commission (FERC) contains sensitive information, and have petitioned the agency to keep the forms confidential. FERC has denied these petitions, but promised to consider the issue further in 2000 (FERC 1999). EIA announced that, as of 1999, they will no longer collect data on plant retirement dates, planned generating capacity, projected fuel consumption, changes to existing generating units, fuel inventory stocks, plant heat rates, and sales to other end users (EIAc 1999). However, EIA is publishing monthly generation data from non-utility power plants, data it previously kept confidential (EIAb 1999).

Besides data availability, changes in electric power industry structure may also affect REPiS. In essence, REPiS is designed to capture utility-owned renewable electric facilities, or non-utility renewable electric facilities that sell power to a single utility, such as a power sales contract under PURPA. In a restructured market, different types of entities will own, buy, or market generation. Renewable electric facilities in a post-restructured electric power market could sell output to a power exchange, individual customers, customer aggregators, to several utilities, or to any combination of the above. Finally, renewables may be developed in different market niches, such as for green power markets, or for distributed power applications, which REPiS is not currently designed to capture. These possible changes in industry and market structure may require REPiS to be redesigned in the future. 


\section{Summary}

REPiS is a database of grid-connected renewable electric facilities. The purpose of the database is to catalog all known renewable electric facilities in the United States, and make the data publicly available. REPiS is a useful tool for researchers who want more detailed information on individual projects, renewable energy companies, or small renewable energy projects not cataloged elsewhere. Users can also sort or manipulate data on renewable electric plants for their own individual needs.

This edition of REPiS includes data on $137 \mathrm{GW}$ of renewable electric plants, with $111 \mathrm{GW}$ of operating renewable electric plants; $3 \mathrm{GW}$ of planned renewable electric plants; and another $23 \mathrm{GW}$ of renewable electric plants that are either retired, on standby, out of service, for which the operating status is unknown. Hydro accounts for over 112 of the $137 \mathrm{GW}$ in REPiS, and biomass amounts to more than two-thirds of the non-hydro capacity in REPiS.

REPiS has slightly less capacity data than what is published by EIA, although there are significant differences by renewable energy technology. EIA does not collect data on facilities of less than $1 \mathrm{MW}$ in capacity, whereas REPiS has no capacity restriction. This probably explains why REPiS has more photovoltaics capacity than EIA. However, REPiS has less geothermal, hydro, and solar thermal capacity than EIA.

Finally, electric restructuring will change how data on electric power is collected, and this may change future editions of REPiS. As electric markets become competitive, electric companies and suppliers will become more reluctant to reveal data that they consider sensitive. EIA recently announced they will withhold some data they previously published, and FERC plans to examine this issue more closely in the near future. 


\section{References}

“Altair Energy Partners with Colorado Utility to Install 40 School PV Systems by 2000." (December 18, 1998). The Solar Letter; Vol. 8, No. 26, pp. 425-426.

"Amergen to Buy 619-MW Nuclear Plant in New Jersey from GPU for \$10 Million" (September 17, 1999). Global Power Report.

American Electric Power Company. "AEP Announces 12 More Schools to Join Fledgling Solar Schools Program." American Electric Power Company Press Release, May 5, 1999. American Electric Power Company online, http://www.aep.com. Accessed August 10, 1999.

American Wind Energy Association. (1999a). "1999 is Best Year Ever for Global Wind Energy Industry." (Last modified December 23, 1999). The American Wind Energy Association online, http://www.awea.org/news/news991223glo.html. Accessed December 28, 1999.

American Wind Energy Association. (1999b). "President Clinton Signs Wind Energy Tax Credit Extension Into Law." (Last modified December 17, 1999). The American Wind Energy Association online, http://www.awea.org/news/news991217ptc.html. Accessed December 28, 1999.

“At Dish/Stirling-Engine Unveiling, Global Potential of System's Market Addressed." (June 19, 1998). The Solar Letter; Vol. 8, No. 13; p. 233: KLA Publishing.

Badger, P. (September 29, 1999). Personal communication. General Bioenergy Inc.

Bain, R. (1993). "Electricity from Biomass in the United States: Status and Future Direction." Bioresource Technology. Elsevier Science Publishers Ltd.; pp. 86-93.

"Bangor Hydro Gets Rate Cuts for 25-MW KTI/NRG Unit Via Funding Transactions." (July 10, 1998). Global Power Report; p. 22.

Berenyi, E.B.; Gould, R. (1993). 1993-94 Resource Recovery Yearbook and Directory. Westport, CT: Governmental Advisory Associates.

Berenyi, E. (1999a). 1999-2000 Methane Recovery from Landfill Yearbook. Westport, CT: Governmental Advisory Associates.

Berenyi, E. (1999b). Personal communication. June 7, 1999.

Berenyi, E. (1997). The Municipal Waste Combustion Industry in the United States: 1997-98 Resource Recovery Yearbook and Directory. (1997). Westport, CT: Governmental Advisory Associates.

Berquist, D. (September 1, 1998). Personal communication. Michigan Public Service Commission. Billing, K. (July 19, 1999). Personal communication. South Carolina Energy Office. 
Bird, Lori; Swezey, Blair (Last modified October 23, 1999). "Estimates of Renewable Energy Developed to Serve Green Power Markets." Green Power Network, http://www.eren.doe.gov/greenpower/new_gp_cap.shtml. Accessed October 28, 1999.

"Bonneville Power Administration Unveils Schedule for Wind, Geothermal Projects." (June 19, 1998). The Solar Letter; Vol. 8, No. 13, p. 242.

"C\&SW Announces Two Renewable Energy Pacts; One Results in 75-MW Wind Farm." (February 23, 1998). Electric Utility Week; p. 10.

CalEnergy Co. (September 17, 1998). CE Turbo Project Award Package to the California Energy Commission.

CalEnergy Co. (September 17, 1998). Salton Sea Unit 5 Project Award Package to the California Energy Commission.

"CalEnergy to Sell Half Its IPP Capacity to El Paso Energy for \$259 Million.” (March 1, 1999). Electric Utility Week; p. 5.

“CalEnergy Worldwide Generating Projects 1999." (Date last modified unknown). CalEnergy online, http://www.midamerican.com/calenergy/html/worldwide2.shtml. Accessed November 3, 1999.

California Energy Commission (1998). "Conditional Funding Awards Under Notice of Auction 50097-506.” (Last modified June 10, 1999). California Energy Commission online, http://www.energy.ca.gov./renewables/new_renewables.html. Accessed November 3, 1999.

"California PUC Approves Socal Edison and SDG\&E BRPU Settlements for \$97 Million." (December 25, 1998). Global Power Report; pp. 18-19.

"California PUC Rejects IPP-Utility Buy-Out Plan to Settle QF Payments." (January 22, 1999). Global Power Report; p. 14.

“Calpine Purchases 72 MW Geothermal Power Plant; Acquisition Strengthens Company's Leadership in Green Power Market.” (July 20, 1998). Business Wire Press Release, p. 1.

Calvert, G. (July 8, 1999). Personal communication. Resource Technology Corporation.

Campbell, N. (April 29, 1999). Personal communication. Minnesota Department of Public Service. Campliagno, T. (July 20, 1999). Personal communication. Baltimore Gas \& Electric.

"Catamount Energy Closes on 80-MW Hydro Project in Summersville, W. Va." (January 22, 1999). Global Power Report; p. 4.

“CL\&P Reaches Agreement to Sell Non-Nuclear Generation Facilities.” (Last modified July 6, 1999). Northeast Utilities on-line, http://www.nu.com/news/news.htm. Accessed August 24, 1999.

Comer, K. (September 16, 1999). Personal communication. Antares Corporation, Landover, Maryland. 
"Con Ed Energy Takes Over 290 MW in Divestiture by NU Mass. Division." (August 6, 1999). Global Power Report; p. 27.

"Con Ed Sells Last of its NYC Plants, Picking Orion Power to Buy 1,855 MW." (March 8, 1999). Electric Utility Week; p. 10.

"Conectiv Strikes Buyout Deal with Ref-Fuel for 75 MW Plant." (August 6, 1999). Global Power Report; p. 27.

Conover, K. (October 12, 1999). Personal communication. Global Energy Concepts.

"Construction Begins on 25-MW PSCO Wyoming Wind Project." (April 6, 1999). Wind Energy

Weekly; Vol. 18, No. 842, p. 3.

Creasy, D. (January 4, 1999). Personal communication. North Carolina Utilities Commission.

Crimp, P. (September 17, 1999). Personal communication. Alaska Division of Energy.

"Current U.S. Utility Connected Wind Power Projects." (April 1999). Published by the American Wind Energy Association.

Darr, G. (July 21, 1999). Personal communication. Bonneville Power Administration.

"Database of California Power Plants." (Last modified June 11, 1999). California Energy Commission online, http://www.energy.ca.gov./database/index.html\#powerplants. Accessed November 3, 1999.

Donovan, C.T. (December 1997). The Great Lakes Directory of Biomass Energy Facilities. Chicago, IL: Great Lakes Regional Biomass Energy Program, Council of Great Lakes Governors Inc.

"DTE Energy Subsidiary to Develop Solar Energy in California Power Park." PRNewswire press release, September 13, 1999, p. 1.

"During First Six Months, Wind Turbine Performance Is Right on Target." (June 23, 1999). Lincoln Electric System press release. Available at http://www.les.lincoln.ne.us/News/Releases/.

EIAa. (December 1999). Electric Power Annual 1998, Vol. II. DOE/EIA-0348(98)/1. Washington, D.C.: Energy Information Administration, U.S. Department of Energy.

EIAb. Energy Information Administration, U.S. Department of Energy. (Last modified December 1999). "Monthly Nonutility Power Plant data-EIA-900 data file,"

http://www.eia.doe.gov/cneaf/electricity/page/eia900.html. Accessed December 28, 1999.

EIAc. Energy Information Administration, U.S. Department of Energy. (Last modified October 1999). "Confidentiality of Information on EIA Electric Power Surveys," http://www.eia.doe.gov/cneaf/electricity/forms/sselecpower98.html. Accessed November 8, 1999. 
EIAd. (December 1998). Renewable Energy Annual 1998 with Data for 1997. DOE/EIA-0603(98). Washington, D.C.: Energy Information Administration, U.S. Department of Energy.

EIAe. (December 1998). Inventory of Power Plants in the United States as of January 1, 1998. DOE/EIA-0095(98). Washington, D.C.: Energy Information Administration, U.S. Department of Energy.

EIAf. (Last modified September 20, 1999). Electric Power Monthly-September 1999. Energy Information Administration online, http://www.eia.doe.gov/cneaf/electricity/epm/epm_sum.html. Accessed October 20, 1999.

EIAg. Energy Information Administration, U.S. Department of Energy. (Last modified June 24 1998). "Electric Power Restructuring: A Focus Group Summary: Implications For Data Collection, Analysis, And Reporting on the Electric Power Industry," http://www.eia.doe.gov/cneaf/electricity/chg_str/focus/toc.html. Accessed October 28, 1999.

FERC 1999a. "Hydroelectric Projects Under Commission License." (Last modified October 29, 1999). Federal Energy Regulatory Commission online, http://www.ferc.fed.us/hydro/hydro2. Accessed November 3, 1999.

FERC 1999b. "Hydroelectric Projects Exempted From Licensing Requirements." (Last modified October 29, 1999). Federal Energy Regulatory Commission online, http://www.ferc.fed.us/hydro/hydro2. Accessed November 3, 1999.

"Financial Incentives Auction a Success for California Energy Technologies." (Last modified July 9, 1998). California Energy Commission online, http://www.energy.ca.gov/releases/1998_releases/9807-09 renewables.html. Accessed November 3, 1999.

Fingerson, D. (July 13, 1999). Personal communication. Goodhue County Cooperative Electric Association.

"FPL Energy to Develop Iowa Wind Generation Projects." (Last modified March 12, 1998). FPL Energy online, http://www.fplenergy.com/. Accessed November 3, 1999.

"FPL Energy to Supply Wind Energy to WEPCO and Alliant Energy." (Last modified September 20, 1999). FPL Energy online, PR Newswire, http://www.fplenergy.com/. Accessed November 3, 1999.

"FSEC Interconnects 11-kWp PV System to Florida Power \& Light Electric Grid." (August 1, 1998). The Solar Letter; Vol. 8, No. 16.

Georgia Power 1997 Non-Utility Report to the Georgia Public Service Commission. (April 1998). Atlanta, GA: Georgia Power Company.

Gillette, L. (August 25, 1999). Personal communication. U.S. Department of Energy.

"GRCPower Geothermal Database." (Date last modified unknown). Geothermal Resources Council online, http://www.geothermal.org/grcpower.html. Accessed November 3, 1999. 
"Green-Market PV Power Begins Flowing at Sun Power Station in Massachusetts." (December 18, 1998). The Solar Letter. Published by KLA Publishing. Vol. 8, No. 26; p. 424.

"Green Mountain Energy Resources Announces Plans to Construct Pennsylvania's Largest Solar Power Plant.” (October 28, 1998). Business Wire press release, p. 1.

"Green Mountain Rolls Out Product Mix in Pennsylvania." (November 16, 1998). Wind Energy Weekly; Vol. 17, No. 823, p. 3.

"GreenMountain.com Announces First Commercial Solar Plant to Be Constructed As a Result of Customer Choice.” (September 7, 1999). PR Newswire press release, p. 1.

Hagan, D. (July 19, 1999). Personal communication. New Mexico Energy Conservation Division.

Hannen, R. (July 13, 1999). Personal communication. Alliant Energy Corporation.

"Houston Utility Agrees to Wind Purchase." (February 17, 1999). Wind Energy Weekly; Vol. 18, No. 835, p. 2.

Hull, C. (July 12, 1999). Personal communication. Zapco.

"Hydro Projects: Putting More Hydroelectric Power On-Line." Alaska Power and Telephone online, http://www.alaskapt.com/services/hydro.html. Accessed November 3, 1999.

Hydro Review 1997. "Tracking the Pioneers of Hydroelectricity.” (October 1997). Hydro Review.

Integrated Resource Plan: Status of Private Power Producers and Demand-Side Management, Including Projected Avoided Costs. (April 1, 1998). Hartford, CT: Connecticut Light and Power.

Interagency Geothermal Coordinating Council and Princeton Economic Research, Inc. (December 1997). Geothermal Progress Monitor Report No. 19. DOE/EE-1160. Washington, D.C.: U.S. Department of Energy.

Interagency Geothermal Coordinating Council and Princeton Economic Research, Inc. (December 1996). Geothermal Progress Monitor Report No. 18. DOE/EE-0121. Washington, D.C.: U.S. Department of Energy.

Jenkins, M. (July 9, 1999). Personal communication. Arkansas Economic Development Commission.

Jones, J. (September 27, 1999). Personal communication. Bangor Hydro-Electric Company.

Keels, K. (August 3, 1999). Personal communication. Duke Energy Company.

Kerstetter, J. D. (December 1998). 1998 Washington State Directory of Biomass Facilities. Report No. WSUEEP99002. Olympia, WA: Washington State University Cooperative Extension Energy Program. 
"Klickitat Landfill Gas Project Fact Sheet.” (Last modified September 16, 1999). Klickitat Public Utilities District online, http://www.klickpud.com/power/lfg.asp. Accessed November 3, 1999.

"Klickitat Landfill Gas-to-Energy Project Dedication.” (Last modified June 9, 1999). Snohomish County Public Utilities District online, http://www.snopud.com/releases/060999.htm. Accessed November 3, 1999.

Kokmen, L. “Against the Grain.” (Last modified September 29, 1999). City Pages online, http://www.citypages.com/databank/20/982/article8014.asp. Accessed November 3, 1999.

Korosec, . (August 27, 1999). Personal communication. California Energy Commission.

Kovac, A. (July 12, 1999). Personal communication. Iowa Energy Bureau.

Lacki, A. (July 14, 1999). Personal communication. GPU Energy.

LaSalla, R. (July 19, 1999). Personal communication. U.S. Department of Energy.

Martin, G. (April 7, 1999). Personal communication. Alaska Power \& Telephone Company.

McGowin, C. (September 15, 1999). Personal communication. Electric Power Research Institute.

"Merchant Plant Rates of Return Likely to Head Down Say Players." (September 3, 1999). Global Power Report; pp. 1, 3-4.

Metro Wastewater Reclamation District Fact Sheet. (June 5, 1999). Metro Wastewater Reclamation District, Denver, Colorado.

"MidAmerican Energy Holdings Co. 1998 Annual Report." (Date last modified unknown).

MidAmerican Energy online, http://www.midamerican.com/index2.html. Accessed November 3, 1999.

"MidAmerican Energy Holdings Company 1998 10-K." (Date last modified unknown).

MidAmerican Energy online, http://www.midamerican.com/index2.html. Accessed November 3, 1999.

"Million Solar Roofs Registry." (Last modified July 7, 1999).

http://www.eren.doe.gov/millionroofs/register.html. Accessed October 18, 1999.

"Minnesota PUC Orders Another 400 MW of Wind Capacity." (January 25, 1999). Wind Energy Weekly; Vol. 18, No. 832, p. 4.

"NEP Deal with Ogden Waste-to-Energy Plant Seen Reducing Stranded Costs." (August 3, 1998). Electric Utility Week; p. 16.

"New York PSC Rules in Favor of Wind Energy." (June 15, 1998). Wind Energy Weekly; Vol. 17, No. 801, p. 3. 
Newman, J. (September 18, 1999). "Wind Farms Gain Madison, Wisconsin Based Energy Firm as a Customer." The Wisconsin State Journal.

"NHA, EEI, APPA Call on FERC to Vacate Its Order to Tear Down Edwards Dam." (July 27, 1998). Electric Utility Week; p. 13.

"NYSERDA Makes \$5.8 Million Available for N.Y. Wind Project." (November 9, 1998). Wind Energy Weekly; Vol. 17, No. 822, p. 3.

"Niagara Mohawk Completes Sale Of Hydroelectric Plants." (Last modified August 2, 1999). Niagara Mohawk Power Corp. online, http://www.nimo.com/nimotod/newsindx/newsrelease/1999_08_02.html. Accessed November 3, 1999.

"Niagara Mohawk Sells Off 32 MW, \$22.5 million Hydro Plant to Northbrook Energy." (July 23, 1999). Global Power Report; p. 16.

Noble, M. (October 12, 1999). Personal communication. Minnesotans for an Energy Efficient Economy.

"O\&R Completes Sale of Generation Plants to Southern Energy." (Last modified June 30, 1999). Orange \& Rockland Inc. online, http://www.oru.com/news/. Accessed November 3, 1999.

“O\&R, Con Ed Agree to Sell 1,776 MW of N.Y. Plants to Southern Energy.” (November 30, 1998). Electric Utility Week; p. 5.

Ohrenschall, M. “It's a Deal-Washington Water Power, Geothermal Developer Reach Agreement on Power Purchase Contract from Planned Nevada Facility.” (Last modified April 28, 1998). Con.Web online, http://www.newsdata.com/enernet/conweb/. Accessed November 3, 1999.

“Old Harbor Hydroelectric Project.” (Date last modified unknown). Alaska Village Electric Cooperative Inc. online, http://www.avec.org/oldharbor.htm. Accessed November 3, 1999.

Osborn, D. (2000). "Sustained Orderly Development and Commercialization of Grid-Connected Photovoltaics: SMUD as a Case Example.” Pre-print from Advances in Solar Energy XIV 2000. Golden, CO: American Solar Energy Society.

Pacific Gas \& Electric 1999. Cogeneration and Small Power Production Semi-Annual Report to the California Public Utilities Commission. (Last modified July 1999). Pacific Gas \& Electric Co. online, http://www.pge.com/customer_services/business/qf/. Accessed November 3, 1999.

"Paper Company Agrees to Sell Maine Mills, Six Hydro Plants." (August 1999). Hydro Review; Vol. XVIII, No. 5, p. 4.

Parsons, B. (October 12, 1999). Personal communication. National Renewable Energy Laboratory, Golden, Colorado.

Pearson, R. (July 10, 1999). Personal communication. Colorado Office of Energy Conservation. 
Phillips, M. (July 16, 1999). Personal communication. PECO Energy.

Power Generation Markets Quarterly. (June 1999). Second Quarter 1999.

"Power Plant Divestiture." (Last modified January 1999). Eastern Utilities Online, http://www.eua.com/divest1.html. Accessed November 3, 1999.

Price, H. (October 15, 1999). Personal communication. National Renewable Energy Laboratory, Golden, Colorado.

"Project On-Line: Glen Falls.” (August 1998). Hydro Review; Vol. XVIII, No. 4, pp. 134-35.

PV System. (April 1998). Washington, DC: Utility Photovoltaics Group.

Rawls, T. (September 16, 1999). Personal communication. Greenmountain.com.

Reed, M. (July 8, 1999). Personal communication. U.S. Department of Energy.

Reese, P. (1998). U.S. Biomass Electric Generating Facilities. Somis, CA: California Biomass Energy Alliance.

Rural Hydroelectric Assessment and Development Study, Phase I Report. (August 18, 1997). Work performed by Locher Interests Ltd. Anchorage, AK: Alaska Division of Energy.

San Diego Gas \& Electric 1999. Cogeneration and Small Power Production Report. (Last modified July 1999). San Diego Gas \& Electric online, http://www.sdge.com/qfi/. Accessed November 3, 1999.

Seren, R. (July 20, 1999). Personal communication. Northern Indiana Public Service Company.

Settje, R. (April 7, 1999). Personal communication. Ketchikan Public Utilities.

Svendsen, T. (July 14, 1999). Personal communication. Klickitat PUD.

Sims, R. (September 20, 1999). Personal communication. SeaWest Windpower, Inc.

Sinclair, K. The Renewable Electric Plant Information System. (1994). NREL/TP-462-7553.

Golden, CO: The National Renewable Energy Laboratory.

Sinclair, K.; Forsyth, T. (1998). “1998 Small Wind Turbine Owner Survey.” Unpublished wind turbine survey by the National Wind Technology Center, NREL.

Sloan, J. (April 13, 1999). Personal communication. U.S. Bureau of Reclamation.

"Socal Edison Inks Alternate Agreement with Eighth of 10 Auction Winners." (November 3, 1995). Independent Power Report; p. 17.

"Socal Edison Wins Approval from PUC to Restructure Contract with Oxbow." (September 17, 1999). Global Power Report. 
Southern California Edison 1999. Qualifying Facilities Production Semi-Annual Status Report to the California Public Utilities Commission. (Last modified July 31, 1999). Southern California Edison online, http://www.sce.com/regulatesca/index_re.htm. Accessed November 3, 1999.

“SRP's Solar Choice." (Date last modified unknown). Salt River Project online, http://www.srpnet.com/home/solarchoice/index.html. Accessed November 3, 1999.

"Status of New Wind Project Development in the U.S." (April 1999). Published by the American Wind Energy Association.

Statz, S. (April 12, 1999). Personal communication. Kennebunk Light and Power District.

Stephens, J. (July 20, 1999) Personal communication. MidAmerican Energy Holdings Co.

Sterling, R. (December 4, 1998). Personal communication. Idaho Public Utilities Commission.

Stockdale, C. (July 12, 1999). Personal communication. Tampa Electric Co.

Swezey, B.; Porter, K. (1990). REPiS: The Renewable Electric Project Information System. SERI/MP-260-4080. Golden, CO: Solar Energy Research Institute.

Swezey, B.; Porter, K. (1988). Report on REPiS: The Renewable Electric Project Information System. Unpublished Report. Golden, CO: Solar Energy Research Institute.

"Tacoma City Light Seeking Business Opportunities for Steam Plant." (Last modified October 27, 1999). Tacoma City Light online, http://www.ci.tacoma.wa.us/tpunews/. Accessed November 3 , 1999.

"Thermo Ecotek Reaches Agreement on Buy Out of 14 MW Maine Plant." (September 3, 1999). Global Power Report.

“Three More Socal Ed Bid Winners Agree to Delay, Cancel Projects.” (December 16, 1994). Independent Power Report; p. 4.

"U.S. Energy Sets Nevada Geothermal Expansion." (Last modified July 12, 1999). U.S. Energy Systems online, http://www.usenergysystems.com. Accessed July 13, 1999.

"USGen Announces Development of Wind Generation Project." (Last modified May 27, 1999). USGen online, http://www.gen.pge.com/news/060100Windpower.htm. Accessed November 3, 1999.

Vallorano, D. (September 20, 1999). Personal communication. Salt River Project.

Walborn, S. (July 16, 1999). Personal communication. FPL Energy.

Walsey, S. (August 4, 1999). Personal communication. Springville City Corporation.

Warner, K. (July 13, 1999). Personal communication. Resource Technology Corporation. 
Washington State Electricity System Study. (December 1998). Olympia, Washington: Washington State Community, Trade and Economic Development, and Washington Utilities and Transportation Commission, Legislative Electricity Study 6550.

Wassmer, J. (April 30, 1999). Personal communication. Owensboro Municipal Utility.

White, J. (July 21, 1999). Personal communication. Oregon Office of Energy.

Williams, S.; Bateman, B. (1995). Power Plays. Washington: Investor Responsibility Research Center.

Wind Projects Database. (1999). Rockville, MD: Princeton Economic Research, Inc., Rockville, Maryland.

"Wind Projects Planned for New York," The Green Power Network, September 8, 1999. Available on-line at http://www.eren.doe.gov/greenpower/ny_899.shtml.

Wiser, R.; Porter, K.; Clemmer, S. (January/February 2000). "Emerging Markets for Renewable Energy: The Role of State Policies." Electricity Journal; pp. 13-24.

"With Constellation Deal, EUA Completes Divestiture of Non-Nuclear Generation." (January 11, 1999). Electric Utility Week. Published by The McGraw-Hill Companies; p. 7.

Wood Fired Power Plants in Maine. (July 1999). Augusta, ME: Maine State Planning Office.

"WPS Resources to Buy 91 MW of Hydro and Fossil Capacity from Maine PS." (July 13, 1998). Electric Utility Week; p. 5.

Young, D. (July 20, 1999). Personal communication. Washington Water Power.

Young, G. (April 29, 1998). Personal communication. Kentucky Division of Energy. 
APPENDIX A

A-1 
Table A-1. Operating Renewable Electric Capacity by State (kW)

\begin{tabular}{|c|c|c|c|c|c|c|c|c|}
\hline State & Biomass & Geothermal & Photovoltaics & $\begin{array}{c}\text { Solar } \\
\text { Thermal } \\
\end{array}$ & Wind & $\begin{array}{c}\text { Non-Hydro } \\
\text { Total Capacity } \\
\end{array}$ & Hydro & $\begin{array}{c}\text { Total Capacity } \\
\text { with Hydro } \\
\end{array}$ \\
\hline Alabama & 743,780 & & & & & 743,780 & $2,859,670$ & $3,603,450$ \\
\hline Alaska & 5,000 & & 10 & & 975 & 5,985 & 392,859 & 398,844 \\
\hline Arizona & 350 & & 1,089 & 75 & 38 & 1,552 & $2,992,406$ & $2,993,958$ \\
\hline Arkansas & 280,700 & & 20 & & & 280,720 & $1,196,720$ & $1,477,440$ \\
\hline California & $1,013,534$ & $2,464,800$ & 9,402 & 353,800 & $1,657,001$ & $5,498,537$ & $13,188,957$ & $18,687,494$ \\
\hline Colorado & 9,605 & & 246 & & 21,600 & 31,451 & $1,164,407$ & $1,195,858$ \\
\hline Connecticut & 281,020 & & 9 & & 55 & 337,009 & 158,085 & 495,094 \\
\hline D.C. & & & 313 & & & 313 & & 313 \\
\hline Delaware & 600 & & 18 & & 2 & 619 & 500 & 1,119 \\
\hline Florida & $1,024,350$ & & 257 & & & $1,024,607$ & 45,310 & $1,069,917$ \\
\hline Georgia & 458,597 & & 357 & & 25 & 458,979 & $3,310,479$ & $3,769,458$ \\
\hline Hawaii & 156,600 & 25,000 & 272 & & 11,200 & 193,072 & 22,777 & 215,849 \\
\hline Idaho & 98,080 & & 18 & & & 98,098 & $2,518,306$ & $2,616,404$ \\
\hline Illinois & 114,106 & & 26 & & & 114,132 & 40,498 & 154,630 \\
\hline Indiana & 10,600 & & 4 & & & 10,604 & 91,420 & 102,024 \\
\hline Iowa & 17,983 & & 6 & & 257,992 & 275,981 & 133,585 & 409,566 \\
\hline Kansas & & & & & 2,879 & 2,879 & 2,728 & 5,607 \\
\hline Kentucky & 4,600 & & 54 & & & 4,654 & 753,367 & 758,021 \\
\hline Louisiana & 524,600 & & & & & 524,600 & 192,000 & 716,600 \\
\hline Maine & 756,250 & & 13 & & 142 & 756,405 & 699,681 & $1,456,086$ \\
\hline Maryland & 137,700 & & 61 & & 4 & 137,765 & 494,550 & 632,315 \\
\hline Massachusetts & 244,380 & & 303 & & 360 & 245,043 & $1,733,235$ & $1,978,278$ \\
\hline Michigan & 483,111 & & 77 & & 657 & 483,845 & $2,412,127$ & $2,895,972$ \\
\hline Minnesota & 255,120 & & 72 & & 274,931 & 530,122 & 212,984 & 743,106 \\
\hline Missouri & 1,300 & & 4 & & & 1,304 & $1,045,000$ & $1,046,304$ \\
\hline Mississippi & 169,821 & & & & & 169,821 & & 169,821 \\
\hline Montana & 12,150 & & & & 130 & 12,280 & $2,452,454$ & $2,464,734$ \\
\hline North Carolina & 360,350 & & 44 & & & 360,394 & $1,951,779$ & $2,312,173$ \\
\hline North Dakota & 9,000 & & & & 849 & 9,849 & 517,750 & 527,599 \\
\hline Nebraska & & & & & 3,660 & 3,660 & 183,930 & 187,590 \\
\hline New Hampshire & 158,163 & & 40 & & 89 & 158,292 & 366,206 & 524,498 \\
\hline New Jersey & 257,300 & & 71 & & & 257,371 & 404,263 & 661,634 \\
\hline New Mexico & & & 76 & & 660 & 736 & 80,020 & 80,756 \\
\hline New York & 470,278 & & 1,053 & & 30 & 471,361 & $5,535,209$ & $6,006,570$ \\
\hline Nevada & & 168,050 & 111 & & 10 & 168,171 & $1,050,735$ & $1,218,906$ \\
\hline Ohio & 81,750 & & 2 & & & 81,752 & 129,000 & 210,752 \\
\hline Oklahoma & 35,000 & & 22 & & 200 & 35,222 & $1,044,285$ & $1,079,507$ \\
\hline Oregon & 271,860 & & 11 & & 24,943 & 296,814 & $8,205,552$ & $8,502,366$ \\
\hline Pennsylvania & 336,980 & & 140 & & 50 & 337,170 & $1,944,053$ & $2,281,223$ \\
\hline Rhode Island & 12,000 & & 19 & & 10 & 12,029 & 6,857 & 18,886 \\
\hline South Carolina & 288,000 & & & & & 288,000 & $3,453,574$ & $3,741,574$ \\
\hline South Dakota & & & & & 10 & 10 & $1,741,058$ & $1,741,068$ \\
\hline
\end{tabular}


Table A-1. Operating Renewable Electric Capacity by State (kW) (continued)

\begin{tabular}{|l|r|r|r|r|r|r|r|r|}
\hline \multicolumn{1}{|c|}{ State } & Biomass & Geothermal & Photovoltaics & $\begin{array}{c}\text { Solar } \\
\text { Thermal }\end{array}$ & Wind & $\begin{array}{c}\text { Non-Hydro } \\
\text { Total Capacity }\end{array}$ & $\begin{array}{c}\text { Hydro } \\
\text { Total Capacity } \\
\text { With Hydro }\end{array}$ \\
\hline Tennessee & 147,785 & & 33 & & & 147,818 & $3,817,420$ & $3,965,238$ \\
\hline Texas & 242,860 & & 956 & & 189,811 & 433,627 & 631,190 & $1,064,817$ \\
\hline Utah & 7,700 & 39,300 & & & 18 & 47,018 & 287,695 & 334,713 \\
\hline Virginia & 419,800 & & 71 & & & 419,871 & $3,087,791$ & $3,507,662$ \\
\hline Vermont & 76,330 & & 12 & & 6,050 & 82,392 & 459,390 & 541,782 \\
\hline Washington & 305,500 & & 7 & 50 & & 305,557 & $20,683,126$ & $20,988,683$ \\
\hline Wisconsin & 284,995 & & & & 21,580 & 306,663 & 511,272 & 817,935 \\
\hline West Virginia & & & & & & 0 & 285,790 & 285,790 \\
\hline Wyoming & & & 46 & & 69,810 & 69,856 & 297,317 & 367,173 \\
\hline Total & $10,658,887$ & $2,697,150$ & 15,432 & 353,925 & $2,601,695$ & $16,237,788$ & $94,789,367$ & $111,027,155$ \\
\hline
\end{tabular}


Table A-2. Planned Capacity by Technology and State (kW)

\begin{tabular}{|c|c|c|c|c|c|c|c|c|}
\hline State & Biomass & Geothermal & Photovoltaics & Solar Thermal & Wind & Total Non-Hydro & Hydro & Total Including Hydro \\
\hline Alaska & & & & & & 0 & 144,960 & 144,960 \\
\hline Alabama & 4,000 & & & & & 4,000 & & 4,000 \\
\hline Arkansas & & & 10 & & & 10 & & 10 \\
\hline Arizona & 2,425 & & 377 & & & 2,802 & & 2,802 \\
\hline California & 67,305 & 104,000 & 10,794 & & 292,380 & 474,479 & 113,000 & 587,479 \\
\hline Colorado & & & 152 & & & 152 & & 152 \\
\hline Connecticut & 2,000 & & 1 & & & 2,001 & & 2,001 \\
\hline Delaware & 1,500 & & & & & 1,500 & & 1,500 \\
\hline Florida & 3,800 & & 299 & & & 4,099 & & 4,099 \\
\hline Georgia & 3,000 & & 15 & & & 3,015 & & 3,015 \\
\hline Hawaii & & & 85 & & & 85 & & 85 \\
\hline Iowa & 3,000 & & & & 600 & 3,600 & & 3,600 \\
\hline Idaho & & & 6 & & & 6 & & 6 \\
\hline Illinois & 65,366 & & 250 & & & 65,616 & & 65,616 \\
\hline Indiana & 4,000 & & & & & 4,000 & & 4,000 \\
\hline Kansas & 3,000 & & & & & 3,000 & & 3,000 \\
\hline Kentucky & & & & & & 0 & 105,000 & 105,000 \\
\hline Louisiana & 3,000 & & 40 & & & 3,040 & & 3,040 \\
\hline Massachusetts & 6,700 & & 74 & & 7,500 & 14,274 & & 14,274 \\
\hline Maryland & & & 60 & & & 60 & & 60 \\
\hline Maine & & & & & 26,000 & 26,000 & 42,700 & 68,700 \\
\hline Michigan & & & 50 & & & 50 & & 50 \\
\hline Minnesota & 65,000 & & 2 & & 425,000 & 490,002 & & 490,002 \\
\hline Missouri & & & & & & 0 & 50,000 & 50,000 \\
\hline North Carolina & & & 3 & & & 3 & & 3 \\
\hline Nebraska & & & & & 660 & 660 & & 660 \\
\hline $\begin{array}{l}\text { New } \\
\text { Hampshire }\end{array}$ & & & 4 & & & 4 & & 4 \\
\hline New Mexico & & & 3,000 & 2,000 & & 5,000 & & 5,000 \\
\hline Nevada & & 91,499 & 50,000 & & 118,500 & 259,999 & & 259,999 \\
\hline New York & & & 45 & & 19,000 & 19,045 & 7,200 & 26,245 \\
\hline Ohio & 5,000 & & 22 & & & 5,022 & & 5,022 \\
\hline Pennsylvania & 1,000 & & 86 & & 10,000 & 11,086 & & 11,086 \\
\hline Rhode Island & & & 3 & & 2,000 & 2,003 & & 2,003 \\
\hline Texas & 6,400 & & 113 & & 224,500 & 231,013 & & 231,013 \\
\hline Utah & & 30,000 & & & & 30,000 & 4,250 & 34,250 \\
\hline Virginia & & & 270 & & & 270 & & 270 \\
\hline Vermont & & & 7 & & 4,620 & 4,627 & & 4,627 \\
\hline Washington & 26,000 & & & & & 26,000 & 32,800 & 58,800 \\
\hline Wisconsin & & & 1,006 & & 30,000 & 31,006 & & 31,006 \\
\hline West Virginia & & & & & & 0 & 80,000 & 80,000 \\
\hline Wyoming & & & & & 13,300 & 13,300 & & 13,300 \\
\hline U.S. Total & 272,496 & 225,499 & 66,773 & 2,000 & $1,174,060$ & $1,740,828$ & 579,910 & $2,320,698$ \\
\hline
\end{tabular}


Table A-3. Summary of Cancelled Capacity in REPiS, by Renewable Fuel Source

\begin{tabular}{|l|c|c|}
\hline \multicolumn{1}{|c|}{ Renewable Fuel Source } & No. of Units & Capacity (kW) \\
\hline Agricultural Waste & 2 & 32,500 \\
\hline Biogas & 16 & 32,806 \\
\hline Energy Crops & 1 & 75,000 \\
\hline Waste-to-Energy & 49 & $1,142,900$ \\
\hline Wood Residues & 10 & 176,400 \\
\hline Total Biomass & 78 & $1,459,606$ \\
\hline Geothermal & 32 & $1,459,100$ \\
\hline Hydro & 191 & $16,293,317$ \\
\hline Photovoltaics & 4 & 108,470 \\
\hline Solar Thermal & 7 & 331,214 \\
\hline Wind & 48 & 716,195 \\
\hline Total & 360 & $20,367,902$ \\
\hline
\end{tabular}

Table A-4. States with the Most Operating Agricultural Waste Capacity in REPiS

\begin{tabular}{|l|c|}
\hline \multicolumn{1}{|c|}{ State } & Capacity (kW) \\
\hline California & 176,550 \\
\hline Hawaii & 107,600 \\
\hline Florida & 25,000 \\
\hline Tennessee & 20,000 \\
\hline Louisiana & 13,000 \\
\hline
\end{tabular}

Table A-5. States with the Most Operating Geothermal Capacity in REPiS

\begin{tabular}{|l|c|}
\hline \multicolumn{1}{|c|}{ State } & Capacity $(\mathbf{k W})$ \\
\hline California & $2,464,800$ \\
\hline Nevada & 168,050 \\
\hline Utah & 39,300 \\
\hline Hawaii & 25,000 \\
\hline
\end{tabular}


Table A-6. States with the Most Operating Hydro Capacity in REPiS

\begin{tabular}{|l|c|}
\hline \multicolumn{1}{|c|}{ State } & Capacity (kW) \\
\hline Washington & $20,683,126$ \\
\hline California & $13,188,957$ \\
\hline Oregon & $8,205,552$ \\
\hline New York & $5,535,209$ \\
\hline Tennessee & $3,817,420$ \\
\hline South Carolina & $3,453,574$ \\
\hline Georgia & $3,310,479$ \\
\hline Virginia & $3,087,791$ \\
\hline Arizona & $2,992,406$ \\
\hline Alabama & $2,859,670$ \\
\hline
\end{tabular}

Table A-7. States with the Most Operating Biogas Capacity in REPiS

\begin{tabular}{|l|c|}
\hline \multicolumn{1}{|c|}{ State } & Capacity (kW) \\
\hline California & 344,089 \\
\hline Illinois & 113,406 \\
\hline Michigan & 77,491 \\
\hline Pennsylvania & 51,300 \\
\hline New Jersey & 40,800 \\
\hline
\end{tabular}

Table A-8. States with the Most Operating Municipal Solid Waste Capacity in REPiS

\begin{tabular}{|l|c|}
\hline \multicolumn{1}{|c|}{ State } & Capacity (kW) \\
\hline Florida & 425,150 \\
\hline Connecticut & 273,000 \\
\hline New York & 264,200 \\
\hline Pennsylvania & 219,000 \\
\hline New Jersey & 216,500 \\
\hline
\end{tabular}

Table A-9. States with the Most Operating Photovoltaics Capacity in REPiS

\begin{tabular}{|l|c|}
\hline \multicolumn{1}{|c|}{ State } & Capacity (kW) \\
\hline California & 9,402 \\
\hline Arizona & 1,089 \\
\hline New York & 1,053 \\
\hline Texas & 956 \\
\hline Georgia & 357 \\
\hline
\end{tabular}


Table A-10. States with the Most Operating Wind Capacity in REPiS

\begin{tabular}{|l|c|}
\hline \multicolumn{1}{|c|}{ State } & Capacity (kW) \\
\hline California & $1,657,001$ \\
\hline Minnesota & 274,931 \\
\hline Iowa & 257,992 \\
\hline Texas & 189,811 \\
\hline Wyoming & 69,810 \\
\hline
\end{tabular}

Table A-11. States with the Most Operating Wood Residue Capacity in REPiS

\begin{tabular}{|l|c|}
\hline \multicolumn{1}{|c|}{ State } & Capacity (kW) \\
\hline Alabama & 738,780 \\
\hline Florida & 547,900 \\
\hline Maine & 541,250 \\
\hline Louisiana & 511,600 \\
\hline Georgia & 456,196 \\
\hline
\end{tabular}


Appendix B

Primary Data Fields

B-1 


\section{Primary Data Fields}

Table B-1. Primary Data Fields

Plant Name(s)

Unit Name

Unit Owner(s)

Plant Location (where available)

Installed Nameplate Capacity

Year of Installation

Technology, System Type, and Fuel Type

Purchasing Utility 


\section{Appendix C}

\section{Plant Name, Location, and Utility Table}

\begin{tabular}{llc}
\multicolumn{3}{c}{ Table C-1. Plant Name, Location, and Utility Table Structure } \\
Field Name & Field Type & Size (in characters) \\
\hline ID Code & Text & 255 \\
Plant Name & Text & 255 \\
Utility Name & Text & 255 \\
Relationship (Code) & Text & 255 \\
Landmark & Text & 255 \\
City & Text & 255 \\
County & Text & 255 \\
State (Code) & Text & 2 \\
Zip & Numeric & \\
\# of Units & Numeric &
\end{tabular}

Table C-2. Relationship between Plant and Utility

\begin{tabular}{ll} 
Relationship Codes & Code Description \\
\hline C & Plant is Contracted to Sell Power to Utility \\
IC & Interconnected with Utility \\
NA & Information is Not Available \\
OP & Utility Owns the Plant
\end{tabular}

Table C-3. State Code and FERC Region

\begin{tabular}{llc} 
State & State Name & FERC Region \\
\hline AK & Alaska & 10 \\
AL & Alabama & 4 \\
AR & Arkansas & 6 \\
AZ & Arizona & 9 \\
CA & California & 9 \\
CO & Colorado & 8 \\
CT & Connecticut & 1 \\
DC & District of Columbia & 3 \\
DE & Delaware & 3 \\
FL & Florida & 4 \\
GA & Georgia & 4 \\
HI & Hawaii & 9 \\
IA & lowa & 7 \\
ID & Idaho & 10 \\
IL & Illinois & 5 \\
IN & Indiana & 5
\end{tabular}

C-1 
Table C-3. State Code and FERC Region

\begin{tabular}{|c|c|c|}
\hline State & State Name & FERC Region \\
\hline$\overline{\mathrm{KS}}$ & Kansas & 7 \\
\hline $\mathrm{KY}$ & Kentucky & 4 \\
\hline LA & Louisiana & 6 \\
\hline MA & Massachusetts & 1 \\
\hline MD & Maryland & 3 \\
\hline $\mathrm{ME}$ & Maine & 1 \\
\hline $\mathrm{Ml}$ & Michigan & 5 \\
\hline MN & Minnesota & 5 \\
\hline MO & Missouri & 7 \\
\hline MS & Mississippi & 4 \\
\hline MT & Montana & 8 \\
\hline $\mathrm{NC}$ & North Carolina & 4 \\
\hline ND & North Dakota & 8 \\
\hline NE & Nebraska & 7 \\
\hline $\mathrm{NH}$ & New Hampshire & 1 \\
\hline NJ & New Jersey & 2 \\
\hline NM & New Mexico & 6 \\
\hline NV & Nevada & 9 \\
\hline NY & New York & 2 \\
\hline $\mathrm{OH}$ & Ohio & 5 \\
\hline OK & Oklahoma & 6 \\
\hline OR & Oregon & 10 \\
\hline PA & Pennsylvania & 3 \\
\hline $\mathrm{RI}$ & Rhode Island & 1 \\
\hline SC & South Carolina & 4 \\
\hline SD & South Dakota & 8 \\
\hline $\mathrm{TN}$ & Tennessee & 4 \\
\hline $\mathrm{TX}$ & Texas & 6 \\
\hline UT & Utah & 8 \\
\hline VA & Virginia & 3 \\
\hline VT & Vermont & 1 \\
\hline WA & Washington & 10 \\
\hline WI & Wisconsin & 5 \\
\hline WV & West Virginia & 3 \\
\hline WY & Wyoming & 8 \\
\hline
\end{tabular}

C-2 


\section{Appendix D}

\section{Unit and Owner Table}

Table D-1. Unit and Owner Table Structure

\begin{tabular}{llc} 
Field Name & Type & Size (in characters) \\
\hline ID Code & Text & 10 \\
Unit Code & Text & 10 \\
Fuel Code & Text & 10 \\
Owner Name & Text & 255 \\
Status Code & Text & 10 \\
Status Yr & Numeric & \\
Tech Code & Text & 10 \\
Sys Type Code & Text & 10 \\
Owner Code & Text & 255 \\
$\%$ of Unit Owned & Numeric & \\
Notes & Text & 255
\end{tabular}

Table D-2. Status Codes

\begin{tabular}{llc} 
Status Code & Description & Classification \\
\hline CN & Cancelled & Retired \\
OP & Operating & Operating \\
PL & Planned (Unit Not Under Construction) & Planned \\
RE & Retired & Retired \\
SB & Standby & Operating \\
TS & Testing & Operating \\
UNK & Unknown & Unknown
\end{tabular}

Table D-3. Technology Codes

\begin{tabular}{ll} 
Tech Code & Description \\
\hline BIO & Bioenergy \\
G & Geothermal \\
H & Hydro \\
P & Photovoltaic \\
ST & Solar Thermal \\
W & Wind
\end{tabular}


Table D-4. System Type Codes

\begin{tabular}{|c|c|}
\hline System Type Code & Description \\
\hline (Blank) & Unknown System Type \\
\hline$A B$ & Atmospheric Fluidized-Bed Clean-Burning Plant (BIO) \\
\hline B & Binary (GEO) \\
\hline C & Concentrating (PV) \\
\hline $\mathrm{CC}$ & Combined Cycle (BIO) \\
\hline CR & Central Receiver (ST) \\
\hline CS & Central Station (PV) \\
\hline D & Distributed (PV) \\
\hline DF & Dual Flash (GEO) \\
\hline DS & Dry Steam (GEO) \\
\hline DSTR & Dish Stirling (ST) \\
\hline FP & Flat Plate (PV) \\
\hline GT & Gas Turbine (BIO) \\
\hline GE & Geothermal - Unknown System Type \\
\hline GP & GeoPressure (GEO) \\
\hline HTC & Hydraulic Turbine Conventional \\
\hline HTP & Hydraulic Turbine Pipeline \\
\hline HTR-PS & Hydraulic Turbine Reversible-Pumped Storage \\
\hline HY & Hydro - Unknown System Type (HTC or HTP) \\
\hline IC & Internal Combustion (BIO) \\
\hline MT & Multiple Turbines (Wind Farm) \\
\hline PD & Parabolic Dish (ST) \\
\hline PS & Pumped Storage $(\mathrm{H})$ \\
\hline PT & Parabolic Trough (ST) \\
\hline SF & Single Flash (GEO) \\
\hline SP & Photovoltaic - Unknown System Type (CS or D) \\
\hline SST & Solar Steam Turbine - Unknown System Type (CR or PD or PT) \\
\hline $\mathrm{ST}<100$ & Single Turbine $<100 \mathrm{~kW}$ \\
\hline $\mathrm{ST}>100$ & Single Turbine $>100 \mathrm{~kW}$ \\
\hline STT & Steam Turbine $(\mathrm{BIO})$ \\
\hline TF & Triple Flash (GEO) \\
\hline WT & Wind Turbine - Unknown System Type (MT or ST) \\
\hline
\end{tabular}

Units using bioenergy (biomass) technology will have system types that depend on the fuel type used. Possible system types for bioenergy are:

$A B$ - Atmospheric fluidized-bed clean-burning plant (all fuel types)

IC - Internal combustion (biogas fuel type)

STT- Steam turbine (all fuel types) 
Table D-5. Fuel Codes

\begin{tabular}{lll} 
Fuel Code & Description & Classification \\
\hline AR & Agricultural Residues (Waste) & Bioenergy \\
BG & Biogas & Bioenergy \\
ER & Energy Crops & Bioenergy \\
GST & Geothermal Steam & Geothermal \\
MSW & Municipal Solid Waste (Including Industrial and Medical) & Bioenergy \\
SUN & Solar & Sun \\
TR & Timber Residues (Milling and Logging Residues) & Bioenergy \\
UNK & Unknown & Unknown \\
WAT & Water & Water \\
WND & Wind & Wind
\end{tabular}

Table D-6. Bioenergy (Biomass) Fuel Code Descriptions

\begin{tabular}{|c|c|}
\hline Bioenergy Fuel Code & Description \\
\hline \multirow[t]{5}{*}{ AR } & Agricultural Residues (Waste) \\
\hline & Cannery Wastes \\
\hline & Nut Hulls \\
\hline & Fruit Pits \\
\hline & Nut Shells \\
\hline \multirow[t]{10}{*}{ BG } & Biogas \\
\hline & Alcohol (Term Includes Butanol, Ethanol, and Methanol) \\
\hline & Bagasse \\
\hline & Hydrogen \\
\hline & Landfill Gas (Refuse Gas) see also METHANE \\
\hline & Livestock Manure \\
\hline & Methane (LGAS or Sewage Gas) Includes Digester Gas \\
\hline & Refuse Gas \\
\hline & Municipal Sewage \\
\hline & Wood Gas (from Wood Gasifier) \\
\hline \multirow[t]{2}{*}{ ER } & Energy Crops \\
\hline & Grains (Corn, Rice, Wheat) \\
\hline \multirow[t]{6}{*}{ MSW } & Municipal Solid Waste (Including Industrial and Medical) \\
\hline & Hazardous Waste \\
\hline & Refuse-Derived Fuel (Combustible Portion of Refuse) \\
\hline & $\begin{array}{l}\text { Refuse (Garbage, Trash) (Brush, Dirt, Food Waste, Grass, Greens, Leather, Leaves, Oils, Paints, Paper, } \\
\text { Plastics, Rags, Rubber, Wood) }\end{array}$ \\
\hline & Scrap Tires (Could be Shredded) \\
\hline & Wastewater Sludge \\
\hline
\end{tabular}


Table D-6. Bioenergy (Biomass) Fuel Code Descriptions

\begin{tabular}{ll} 
Bioenergy Fuel Code & \\
\hline TR & Timber Residues (Milling Residues and Logging Residues) \\
& Tree Bark \\
& Wood Chips (from Milling/Logging) \\
& Hog (Hogged) Fuel \\
& Pulping Liquor \\
& Paper Mill Sludge \\
& Peat \\
& Tree Pitch \\
& Sander Dust (from Milling) \\
& Sawdust (from Milling) \\
& Shavings (from Milling) \\
& Tree Trim (from Milling) \\
& Wood or Wood Waste
\end{tabular}

Table D-7. Owner Codes

\begin{tabular}{cll} 
Owner Code & Description & Classification \\
\hline A & Public Authorities (State, Cities, Counties, etc.) & Publicly Owned \\
C & Cooperatives & Cooperatives \\
F & Federally Owned & Publicly Owned \\
M & Municipal & Publicly Owned \\
N & Nonutilities & Nonutilities \\
P & Investor-Owned Utilities & Investor Owned
\end{tabular}




\section{Appendix E}

\section{Database Design and Methodology}

\section{Database Design}

REPiS includes information on all the renewable energy technologies, including biomass, geothermal, hydroelectric, photovoltaic (PV), solar thermal, and wind. To the extent available, data is divided into the unit level, rather than plant level. Data collected for each renewable energy unit, again depending on availability, includes owner name, plant name, technology type, system type, number of units, fuel type, unit capacity, location, on-line date, operating status, and the purchasing utility of power from a non-utility plant. REPiS consists of six tables, the two most important of which are unit owner and plant location. See Appendices B through D for more details.

Data on the renewable electric units in REPiS is current through mid-1999, except for wood and hydro, for which the data is current through 1998, and in some specific cases, through mid-1999. Information on planned units goes from 2000 to 2013, although some planned units do not have an identified on-line date, either because one has not been announced or because information is unavailable.

Unlike previous editions, this edition of REPiS does not include generation data or revenue and cost data, because of the difficulties of acquiring such data, and because of funding constraints. Data on non-utility projects is filed with the Energy Information Administration (EIA), but plantlevel data is kept confidential. Some electric utilities report purchases from and expenditures paid to non-utility generators; however, this data is not in a standard format, and some utilities do not report it at all. For these reasons, this edition of REPiS was streamlined to focus more on plant ownership, capacity, and operating status.

\section{Methodology}

The data in REPiS comes from publicly available sources, such as federal and state government publications and reports; trade association data sources; trade press literature such as weekly newsletters; and personal communications with industry and government officials. No surveys were conducted to collect data. Information in the database was collected through a massive literature search.

To begin with, the National Renewable Energy Laboratory (NREL) sent a letter in August 1998 to all 50 state public utility commission offices, with printouts from REPiS of renewable electric installations in each state. We received helpful publications and comments from about half of the states. The state data, along with various project-specific trade press articles and personal communications with industry and government officials, were important data sources for all of the renewable electric technologies. In some cases, NREL used company annual report filings to 
the Securities and Exchange Commission (SEC), if a renewable energy company had stock that is publicly traded.

More specific sources of data and methodology is discussed below by technology:

Biomass: REPiS includes data on wood and agricultural waste, as well as waste-toenergy (WTE) and biogas facilities. The primary reference for wood and agricultural waste was an inventory of these facilities prepared by the California Biomass Energy Alliance in 1998 (Reese 1998). The data in this report consisted mostly of plant location, plant capacity, and how much of the plant capacity was consumed at the plant site or delivered to the electric grid. Data in this report was compared to EIA's inventory of non-utility facilities (EIAa 1999).

Co-firing of wood and/or refuse with fossil fuel, primarily coal, is also represented in REPiS. Only facilities that regularly co-fire biomass with fossil fuels were included in REPiS-facilities that co-fired biomass with fossil fuels on a testing or experimental basis were not included. Data sources included EIA (EIAa 1999), and a list of biomass co-firing at fossil electric plants provided by the Antares Corporation (Comer 1999).

Two directories by Governmental Advisory Associates provided the bulk of information used to update the municipal solid waste and landfill methane facilities in REPiS. About $80 \%$ of the waste-to-energy and $70 \%$ of the landfill methane facilities in each report are grid connected, and these were added to REPiS (Berenyi 1997; Berenyi 1999a). NREL also received some updates by Dr. Eileen Berenyi, the author of the two reports (Berenyi 1999b).

Geothermal: The U.S. Department of Energy's (DOE's) Geothermal Office and the Interagency Geothermal Coordinating Council (IGCC) published an annual update of geothermal activities through 1997. The report included a list of geothermal electric plants in the United States (Interagency Geothermal Coordinating Council 1997). Here, trade press articles and company filings to the SEC were critical, as a number of existing geothermal facilities have changed owners since REPiS was last updated. For example, Pacific Gas and Electric (PG\&E) sold its geothermal plants at The Geysers to Calpine Corporation, and the California Energy Company sold a 50\% interest in its geothermal facilities as part of the company's acquisition of MidAmerican Energy Co., an investor-owned utility in Iowa (MidAmerican 1998 10-K). The California Energy Commission's (CEC's) list of winning bidders in the 1998 new renewable resources auction was also used to identify planned geothermal facilities in California (California Energy Commission 1998). REPiS does not include non-grid geothermal facilities, such as geothermal heat pumps.

Hydro: REPiS includes conventional, run-of-the-river, and pumped storage hydro projects. The Federal Energy Regulatory Commission (FERC) provided a list of operating hydro projects (FERC 1999a; FERC 1999b). We also used EIA publications (EIAa 1999).

Solar: The Utility Photovoltaic Group (UPVG), a trade association of electric utilities involved in photovoltaics R\&D and deployment, provided a database of U.S. PV installations that is current through April 1998 (UPVG 1998). DOE's Photovoltaics Program provided an 
electronic spreadsheet of known PV installations in the U.S., using REPiS, the UPVG database, the Million Solar Roofs database, and other databases as sources (Gillette 1999).

Wind: An unpublished 1998 NREL survey of small wind turbine facilities was used for updating these facilities in REPiS (Sinclair and Forsythe 1998). Many sources were used for utility-scale wind facilities, including the American Wind Energy Association's Web site of wind projects (American Wind Energy Association 1999); the CEC list of winning bidders in the new renewable resources auction (California Energy Commission 1998); and a database of wind electric installations provided by Princeton Economic Research, Inc., of Rockville, Maryland (Princeton Economic Research 1999). For wind facilities in California, these data sources were cross-checked with data and ownership provided in biennial qualifying facility reports provided by the three California investor-owned utilities to the California Public Utilities Commission (Pacific Gas \& Electric 1999; San Diego Gas \& Electric 1999; Southern California Edison 1999). 


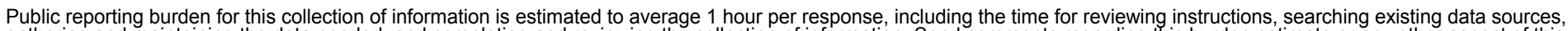

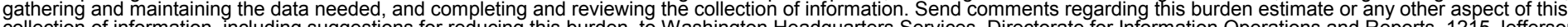

Davis Highway, Suite 1204, Arlington, VA 22202-4302, and to the Office of Management and Budget, Paperwork Reduction Project (0704-0188), Washington, DC 20503.
1. AGENCY USE ONLY (Leave blank)
2. REPORT DATE
3. REPORT TYPE AND DATES COVERED
August 2000
Technical Report

4. TITLE AND SUBTITLE

REPiS: The Renewable Electric Plant Information System-1999 Edition

5. FUNDING NUMBERS

6. $\mathrm{AUTHOR}(\mathrm{S})$

Kevin Porter, David Trickett, and Lori Bird

T: AS65.4010

7. PERFORMING ORGANIZATION NAME(S) AND ADDRESS(ES)

8. PERFORMING ORGANIZATION REPORT NUMBER

9. SPONSORING/MONITORING AGENCY NAME(S) AND ADDRESS(ES)

National Renewable Energy Laboratory

1617 Cole Blvd.

Golden, CO 80401-3393

10. SPONSORING/MONITORING

AGENCY REPORT NUMBER

NREL/TP-620-28674

11. SUPPLEMENTARY NOTES

NREL Technical Monitor: Barbara Farhar

12a. DISTRIBUTION/AVAILABILITY STATEMENT

National Technical Information Service

12b. DISTRIBUTION CODE

U.S. Department of Commerce

5285 Port Royal Road

Springfield, VA 22161

13. ABSTRACT (Maximum 200 words)

This technical report summarizes the data in the Renewable Electric Plant Information System (REPiS), a database of all known grid-connected renewable electric facilities in the United States. It was originally designed in 1985 and updated in 1990 and 1994. The design of the database is discussed; some of the results of common search queries of the database are summarized. Data is presented on the amount of renewable electric capacity nationally that is operated, retired, planned, or of unknown status, as well as operating and planned renewable electric capacity state by state. 14. SUBJECT TERMS
renewable electric capacity; renewable energy database; renewable energy technologies;
electric restructuring

17. SECURITY CLASSIFICATION OF REPORT Unclassified

18. SECURITY CLASSIFICATION OF THIS PAGE Unclassified
19. SECURITY CLASSIFICATION OF ABSTRACT Unclassified
15. NUMBER OF PAGES

16. PRICE CODE

20. LIMITATION OF ABSTRACT

UL

NSN 7540-01-280-5500

Standard Form 298 (Rev. 2-89) Prescribed by ANSI Std. Z39-18 